\title{
Neutrophils Are Critical for Myelin Removal in a Peripheral Nerve Injury Model of Wallerian Degeneration
}

\author{
Jane A. Lindborg, ${ }^{1}$ Matthias Mack, ${ }^{2}$ and ${ }^{\circledR}$ Richard E. Zigmond ${ }^{1}$ \\ ${ }^{1}$ Department of Neurosciences, Case Western Reserve University, Cleveland, Ohio 44106-4975, and ${ }^{2}$ Department of Internal Medicine II, University \\ Hospital Regensburg, 93053 Regensburg, Germany
}

Wallerian degeneration (WD) is considered an essential preparatory stage to the process of axonal regeneration. In the peripheral nervous system, infiltrating monocyte-derived macrophages, which use the chemokine receptor CCR2 to gain entry to injured tissues from the bloodstream, are purportedly necessary for efficient WD. However, our laboratory has previously reported that myelin clearance in the injured sciatic nerve proceeds unhindered in the $C c r 2^{-1-}$ mouse model. Here, we extensively characterize WD in male $C c r 2^{-1-}$ mice and identify a compensatory mechanism of WD that is facilitated primarily by neutrophils. In response to the loss of CCR2, injured $\mathrm{Ccr} 2^{-1-}$ sciatic nerves demonstrate prolonged expression of neutrophil chemokines, a concomitant extended increase in the accumulation of neutrophils in the nerve, and elevated phagocytosis by neutrophils. Neutrophil depletion substantially inhibits myelin clearance after nerve injury in both male WT and $\mathrm{Ccr} 2^{-/-}$mice, highlighting a novel role for these cells in peripheral nerve degeneration that spans genotypes.

Key words: axotomy; macrophages; neutrophils; phagocytosis; sciatic nerve; Wallerian degeneration

\section{Significance Statement}

The accepted view in the basic and clinical neurosciences is that the clearance of axonal and myelin debris after a nerve injury is directed primarily by inflammatory CCR $2^{+}$macrophages. However, we demonstrate that this clearance is nearly identical in WT and $C c r 2^{-1-}$ mice, and that neutrophils replace CCR2 ${ }^{+}$macrophages as the primary phagocytic cell. We find that neutrophils play a major role in myelin clearance not only in $\mathrm{Ccr} 2^{-1-}$ mice but also in WT mice, highlighting their necessity during nerve degeneration in the peripheral nervous system. These degeneration studies may propel improvements in nerve regeneration and draw critical parallels to mechanisms of nerve degeneration and regeneration in the CNS and in the context of peripheral neuropathies.

\section{Introduction}

Removal of axonal and myelin debris after a nerve insult is of paramount importance to ensure regeneration of the injured axons (e.g., Vargas and Barres, 2007). This clearance process,

Received July 24, 2017; revised Sept. 6, 2017; accepted Sept. 9, 2017.

Author contributions: J.A.L. and R.E.Z. designed research; J.A.L. performed research; M.M. contributed unpublished reagents/analytic tools; J.A.L. and R.E.Z. analyzed data; J.A.L. and R.E.Z. wrote the paper.

This work was supported by National Institutes of Health Grants DK097223 and NS095017 to R.E.Z., J.A.L. was supported by NS067431 and F31NS093694. Breeding and genotyping of animals were performed by the Case Western Reserve University Visual Sciences Specialized Animal Research Core (EY11373). We thank Dr. Hisashi Fujioka (Electron Microscopy Core) for preparing semithin nerve sections; Mike Sramkoski (Cytometry and Imaging Microscopy Core at Case Western Reserve University) for providing guidance with flow cytometry setup and analysis; Divya Deverakonda and Natalie Dean for help with analyzing data for semithin nerve sections; and Light Microscopy Imaging Facility at Case Western Reserve University for use of the Leica SP-8 Confocal Microscope (made available through Office of Research Infrastructure Shared Instrumentation Grant S100D016164).

The authors declare no competing financial interests.

Correspondence should be addressed to Dr. Richard E. Zigmond, Case Western Reserve University, Department of Neurosciences, School of Medicine, Room E701, 10900 Euclid Avenue, Cleveland, OH 44106-4975. E-mail: rez@case.edu.

DOI:10.1523/JNEUROSCI.2085-17.2017

Copyright $\odot 2017$ the authors $\quad 0270-6474 / 17 / 3710258-20 \$ 15.00 / 0$ known as Wallerian degeneration (WD), has been extensively studied in models of peripheral and central nerve injuries and diseases. Within the CNS, WD is hampered due to the low efficiency of clearance of inhibitory molecules that obstruct regrowth (Perry et al., 1987; George and Griffin, 1994). This situation does not hold true for the peripheral nervous system where injured nerve fragments rapidly degenerate and are removed from the path of regenerating axons (Griffin et al., 1992, 1994; Vargas and Barres, 2007).

Infiltrating monocyte-derived macrophages are thought to be indispensable for nerve debris clearance after injury in the peripheral nervous system (e.g., Barrette et al., 2008; Gaudet et al., 2011). These hematogenous cells express the chemokine receptor CCR2, which is important for induced monocyte infiltration under inflammatory conditions (Auffray et al., 2007; Nahrendorf et al., 2007). Induction of CCR $2{ }^{+}$monocyte-derived macrophages requires the binding of the receptor CCR2 to monocyte chemoattractant protein-1 (MCP-1, CCL2) released by Schwann cells after injury (Leonard et al., 1991; Toews et al., 1998). Ccr2 deletion drastically reduces the recruitment of inflammatory macrophages to injured tissues (Kurihara et al., 1997; Siebert et al., 
2000). Furthermore, experimental methods that have depleted CCL2 resulted in inhibition of macrophage recruitment in the sciatic nerve and delayed myelin clearance and regeneration (Perrin et al., 2005; Boivin et al., 2007), illustrating a functional role for these macrophages in phagocytosis and removal of debris.

Our laboratory has similarly demonstrated that a Ccr 2 global knock-out substantially impeded macrophage accumulation in the distal sciatic nerve $7 \mathrm{~d}$ following a transection injury. Surprisingly, this inhibition did not hamper myelin clearance (Niemi et al., 2013). The lack of CCR ${ }^{+}$macrophages, which have heretofore been thought necessary for WD, and the parallel evidence that this loss did not impact myelin removal, suggests that a compensatory mechanism of WD exists in the $\mathrm{Ccr} 2^{-1-}$ mouse. Studies that have focused on cellular functions during neuroinflammation point to nonredundant mechanisms among different cell types (Jerath et al., 2010; Ajami et al., 2011). However, by manipulating or deleting cell-specific receptor functions, replacement mechanisms can arise to fulfill that missing role (Kurihara et al., 1997; Kuziel et al., 1997; Saederup et al., 2010). Our work has suggested that a similar compensatory mechanism is at play in the $\mathrm{Cr} 2^{-1-}$ mouse after a peripheral nerve injury.

Which cellular candidates have the capability to perform phagocytosis and clearance of debris? The most obvious option is the Schwann cell. Even before the arrival of hematogenous macrophages, dedifferentiated Schwann cells instigate myelin phagocytosis (Bigbee et al., 1987; Stoll et al., 1989). Aside from Schwann cells, non-CCR $2^{+}$macrophages may aid in myelin removal in the absence of CCR ${ }^{+}$macrophages. Neutrophils, dendritic cells, fibroblasts, and endothelial cells are other known phagocytes that populate peripheral tissues. Neutrophils, in particular, are effective phagocytes, but perhaps their role in WD has been overlooked until recently due to their short lifespan (Borregaard, 2010; Amulic et al., 2012). Rather unexpectedly, we have shown that neutrophils play an impressive role in myelin removal during WD. Neutrophil-specific depletion severely abates nerve debris clearance not only in $\mathrm{Ccr} 2^{-1-}$ mice, but in WT mice as well. Our findings carve out a novel role for neutrophils that better elucidates the process of WD in the peripheral nervous system.

\section{Materials and Methods}

Mice. Male (8-12 weeks old) wild-type (WT) mice (C57BL/6J; The Jackson

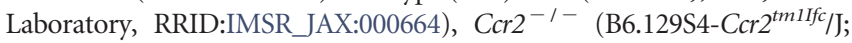
The Jackson Laboratory, RRID:IMSR_JAX:004999), and mixed male and female $C x 3 c r 1^{-1-}$ (B6.129p-Cx3cr1 ${ }^{\text {tm1Litt } / J ; ~ C X 3 C R 1-G F P ; ~ T h e ~ J a c k s o n ~}$ Laboratory, RRID:IMSR_JAX:005582) mice were used for this study. All surgeries, treatments, and experiments were performed on healthy mice. All mice had ad libitum access to food and water and were housed under a $12 \mathrm{~h}$ light/dark cycle.

Injury model. Mice were anesthetized under isoflurane, and the right sciatic nerve was exposed, transected at hip level, and $1 \mathrm{~mm}$ of the nerve was removed. The left sciatic nerve was exposed and served as a shamoperated control. Six hours, or 1, 2, 3, 5, or $7 \mathrm{~d}$ after injury, mice were killed by $\mathrm{CO}_{2}$ inhalation and the sciatic nerves were harvested for analysis. All surgical procedures were approved by the Case Western Reserve University Institutional Animal Care and Use Committee.

Immunohistochemistry. Axotomized and control sciatic nerves were harvested, cleaned, and fixed in 4\% PFA before cryoprotection in 30\% sucrose. Nerves were embedded in Tissue-Tek OCT compound (Electron Microscopy Sciences) and sectioned at $10 \mu \mathrm{m}$ using a cryostat. Primary antibodies were incubated with tissue sections overnight at $4^{\circ} \mathrm{C}$, and subsequently incubated for $1 \mathrm{~h}$ at room temperature in either Cy3 secondary antibody (1:400; Jackson ImmunoResearch Laboratories, [rat] catalog \#711-546-152, RRID:AB_2340619; [sheep] catalog \#713166-147, RRID:AB_2340729), or AF488 secondary antibody (1:400; Jackson ImmunoResearch Laboratories, [rabbit] catalog \#711-546-152,
RRID:AB_2340619; [rat] catalog \#712-545-153, RRID:AB_2340684; [mouse] catalog \#715-546-150, RRID:AB_2340849). DAPI (1:1000; Invitrogen, catalog \#D1306, RRID:AB_2629482) was used to label cell nuclei. Antibodies used for IHC and immunocytochemistry include rat monoclonal antibodies to CD68 (1:200; Bio-Rad, catalog \#MCA1957, RRID:AB_322219), CD11b (1:200; Abcam, catalog \#ab64347, RRID: AB_1140550), or rabbit polyclonal antibody to ionized calcium-binding adaptor molecule 1 (Iba1; 1:300; Wako Laboratory Chemicals, catalog \#019-19741, RRID:AB_839504) to detect macrophages; rabbit polyclonal antibodies to GFAP (1:400; Dako, catalog \#Z0334, RRID: AB_10013382), S100 (1:200; AbD Serotec, catalog \#AHP385, RRID: AB_323128), or p75 (1:400; Abcam, catalog \#ab8874, RRID:AB_306827) to detect Schwann cells; rat monoclonal antibody to Ly6G (clone 1A8; 1:250; BD Biosciences, catalog \#551459, RRID:AB_394206) to detect neutrophils; rabbit monoclonal antibody to myelin basic protein (MBP) (1:300; Cell Signaling Technology, catalog \#78896) or rabbit polyclonal antibody to myelin protein zero (1:500; Abcam, catalog \#ab31851, RRID: AB_2144668) to detect myelin; mouse monoclonal antibody to CD11c (1:150; Abcam, catalog \#ab11029, RRID:AB_297683) to detect dendritic cells; rabbit polyclonal antibody to fibronectin (1:200; Abcam, catalog \#ab2413, RRID:AB_2262874) to detect fibroblasts; and sheep polyclonal antibody to von Willebrand Factor (1:100; Abcam, catalog \#ab11713, RRID:AB_298501) to detect endothelial cells. Images were captured at either $25 \times$ magnification using SimplePCI software (Hamamatsu) or $40 \times$ magnification (Leica SP8) using Application Suite X software (Leica Biosystems). Quantification was performed using MetaMorph software (version 7.6.3.0; Molecular Devices, RRID:SCR_002368). Three images per nerve were captured (quantification excluded the injury site and $\sim 1$ $\mathrm{mm}$ distal to the injury site). The area of the section that was stained is expressed as a percentage of the total area examined. Positive cell counts were determined based on the colocalization of DAPI (with the exception of the Oil Red O [ORO] assay) with the cellular marker using Image software (1.48 version, RRID:SCR_003070).

Western blotting. Single nerves were homogenized using a RIPA Lysis Buffer System (Santa Cruz Biotechnology), and protein concentrations were determined using a Pierce BCA Protein Assay kit (Thermo Scientific). Protein homogenates were analyzed by SDS-PAGE in Bis-Tris (Invitrogen) gels run at $150 \mathrm{~V}$ for $1.5 \mathrm{~h}$. Proteins were transferred to PVDF membranes in NuPAGE transfer buffer (Invitrogen) containing 10\% methanol at $30 \mathrm{~V}$ for $1.25 \mathrm{~h}$ at $4^{\circ} \mathrm{C}$. Before blocking, membranes were incubated in a Sypro Ruby total protein stain (Invitrogen) to represent a loading control since common housekeeping proteins, such as actin and GAPDH decreased after axotomy. Membranes were blocked in TBST containing 5\% BSA for $1 \mathrm{~h}$ at room temperature, and subsequently incubated overnight at $4^{\circ} \mathrm{C}$ with either a rabbit polyclonal antibody to neurofilament-light (1:2000; Covance, catalog \#PRB-574C, RRID: AB_291699) or a rabbit polyclonal antibody to myelin protein zero (1: 2000; Abcam, catalog \#ab31851, RRID:AB_2144668). Membranes were washed in TBST and incubated in a HRP secondary antibody (1:2000; Jackson ImmunoResearch Laboratories, catalog \#711-036-152, RRID: AB_2340590) for $1 \mathrm{~h}$ at room temperature. Membranes were imaged using FluorChem M ProteinSimple system (Biotechne) and a chemiluminescence WesternBright ECL kit (Advansta). Three mice per genotype per time point were used. Band density values were determined using ImageJ software, and graphs represent raw data.

Semithin nerve sections and toluidine blue staining. For further examination of myelin profiles, WT and $C \mathrm{cr} 2^{-1-}$ mice were anesthetized using a ketamine/xylazine mixture ( $20 \mathrm{mg} / \mathrm{ml}$ ketamine; $2 \mathrm{mg} / \mathrm{ml}$ xylazine) $7 \mathrm{~d}$ after sciatic nerve transection, and perfused with $2 \% \mathrm{PFA} / 2.5 \%$ glutaraldehyde solution (Karnovsky's fixative; Electron Microscopy Sciences) at a flow rate of $10 \mathrm{ml} / \mathrm{min}$. Injured and sham-operated nerves were postfixed for $2 \mathrm{~h}$ at room temperature in triple aldehyde-DMSO (Fujioka et al., 2012). After rinsing in PBS, pH 7.3, nerves were postfixed in ferrocyanide-reduced osmium tetroxide, rinsed in PBS, and incubated overnight in acidified uranyl acetate. Nerves were rinsed in $\mathrm{H}_{2} \mathrm{O}$, dehydrated in ascending concentrations of ethanol, passed through propylene oxide, and embedded in Poly/Bed resin mixture (Polysciences). Longitudinal and cross-sections $(0.7 \mu \mathrm{m})$ were cut with a diamond knife, stained with $1 \%$ toluidine blue solution, and imaged using light micros- 
A

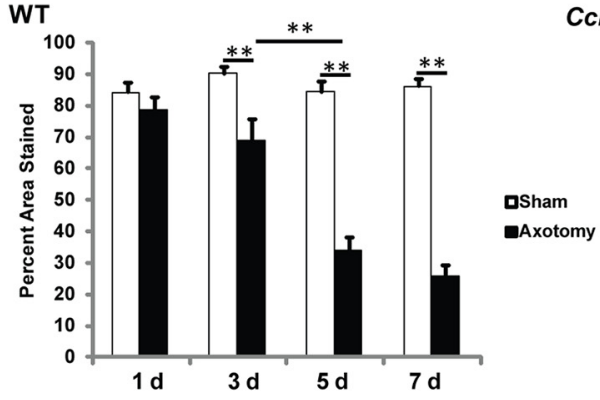

B

cer2-l-

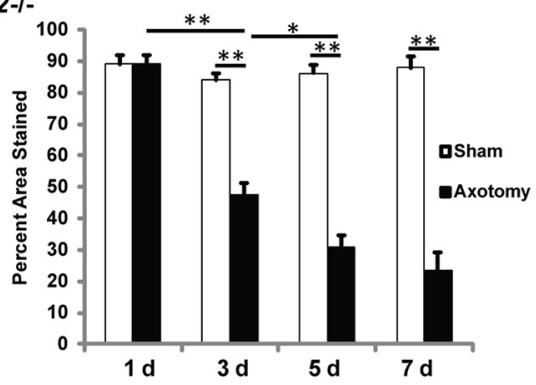

C

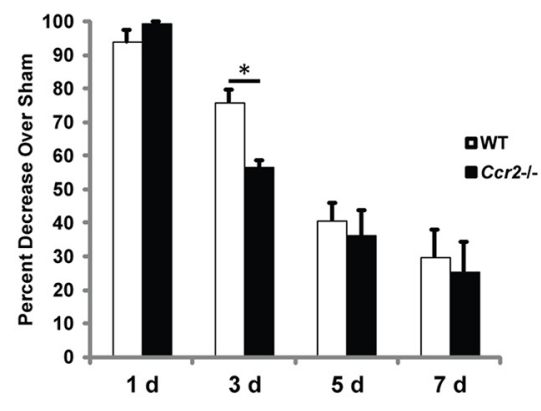

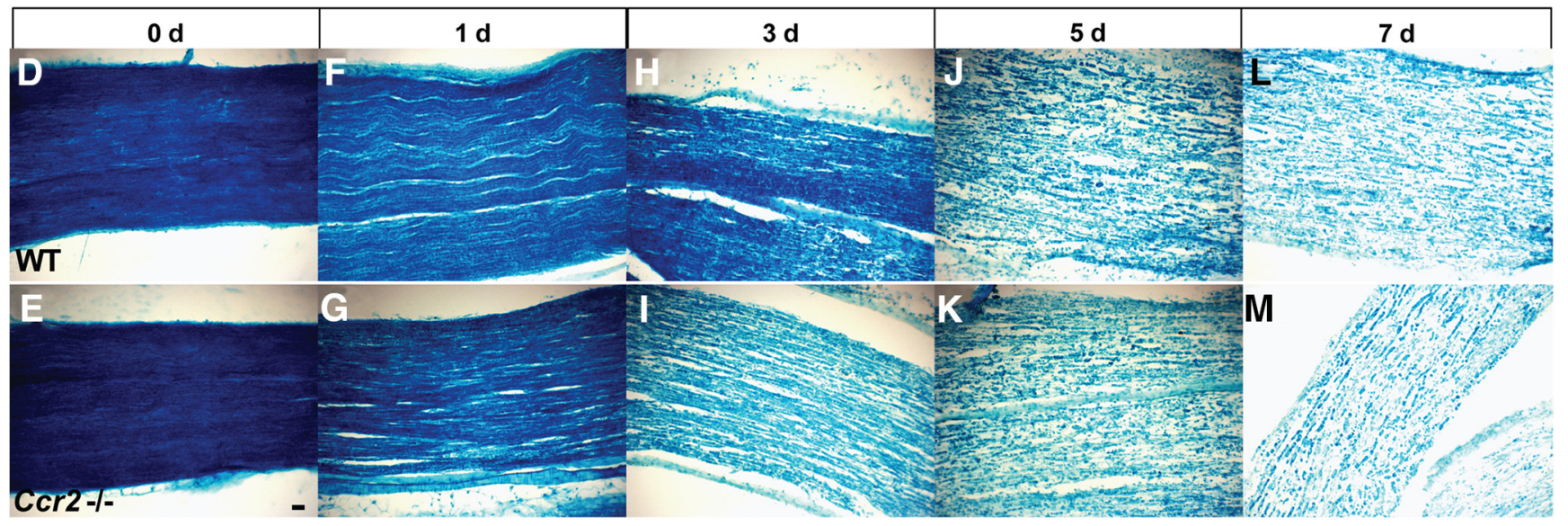

Figure 1. Time course of myelin clearance shows significantly more myelin removal in $\mathrm{Ccr}^{-/-}$nerves than in WT nerves at $3 \mathrm{~d}$ after axotomy. $\boldsymbol{A}$, Luxol fast blue staining represented as a percentage area stained for WT nerves. $n=4$ or 5 mice per genotype per time point. Between injury: $F_{(1,34)}=149.76 .{ }^{* *} p<0.001$ (AN0VA). Between time points: $F_{(3,32)}=18.05$. ${ }^{* *} p<0.001$ (ANOVA). B, Luxol fast blue staining represented as a percentage area stained for $\left(\mathrm{cr} 2^{-l-}\right.$ nerves. $n=4$ or 5 mice per genotype per time point. Between injury: $F_{(1,40)}=182.07 .{ }^{* *} p<0.001$ (ANOVA). Between time points: $F_{(3,38)}=20.41 .{ }^{*} p=0.006$ (ANOVA). ${ }^{* *} p<0.001$ (ANOVA). C, Luxol fast blue staining represented as a percentage decrease over sham-operated nerves. Data are represented as the average of two separate experiments wherein each time point has $n=4$ or 5 mice per genotype. $t_{(2)}=4.46,{ }^{*} p=0.046$ (two-tailed $t$ test). $D$ - $M$, Representative micrographs of axotomized nerves comparing myelin clearance between WT $(\boldsymbol{D}, \boldsymbol{F}, \boldsymbol{H}, \boldsymbol{J}, \boldsymbol{L})$ and $\left(\boldsymbol{C} r 2^{-I-}(\boldsymbol{E}, \mathbf{G}, \boldsymbol{I}, \boldsymbol{K}, \boldsymbol{M})\right.$ mice at $0 \mathrm{~d}(\boldsymbol{D}, \boldsymbol{E}), 1 \mathrm{~d}(\boldsymbol{F}, \boldsymbol{G}), 3 \mathrm{~d}(\boldsymbol{H}, \boldsymbol{I}), 5 \mathrm{~d}(\boldsymbol{J}, \boldsymbol{K})$, and $7 \mathrm{~d}(\boldsymbol{L}, \boldsymbol{M})$ after injury. Scale bar, $20 \mu \boldsymbol{\mu m}$.

copy. Quantification of $100 \times$ magnification images was done by averaging data from 5 animals per genotype ( 5 images per animal per injury condition). Cell counts and g-ratios were performed using ImageJ software. The g-ratio, a measure of myelination, was calculated by first measuring the area of the fiber excluding myelin and the area of the fiber including myelin. The diameters of the axon and the fiber were derived from the area measurements, and the g-ratio was calculated by dividing the axon diameter by the fiber diameter. Only fibers with intact, undisrupted myelin sheaths were included in this measurement. Degenerating fibers were identified by disruption of the myelin sheaths, and phagocytic cells were identified by their white, "foamy" morphology that is indicative of myelin and lipid degradation.

Flow cytometry. Single sciatic nerves were enzymatically digested in $0.125 \%$ collagenase for $1 \mathrm{~h}$ at $37^{\circ} \mathrm{C}$. Mechanical digestion using a 23 gauge needle attached to a $1 \mathrm{ml}$ syringe produced single-cell suspensions, which were filtered through a $35 \mu \mathrm{m}$ cell strainer. For blood analysis, mice were anesthetized using a ketamine/xylazine mixture and blood was collected by cardiac puncture. Red blood cells were lysed with a hypotonic solution. Dead cells were labeled using Live Dead Fixable Blue Dead Cell Stain kit (Invitrogen, catalog \#L23105) for $30 \mathrm{~min}$ at $4^{\circ} \mathrm{C}$. Cells were then washed in FACS buffer (PBS, 1\% BSA) and blocked with a monoclonal antibody to CD16/CD32 (1:500; eBioscience, catalog \#14-016182, RRID:AB_467133) for $10 \mathrm{~min}$ at $4^{\circ} \mathrm{C}$. Cells were incubated with fluorophore-conjugated antibodies against Ly6C, Ly6G (1A8), CD11b, F4/80, and p75 (1:400; BioLegend, [Ly6C] catalog \#128023, RRID: AB_10640119; [Ly6G] catalog \#127610, RRID:AB_1134159; [CD11b] catalog \#101206, RRID:AB_312789; [F4/80] catalog \#123130, RRID: AB_2293450; [p75] catalog \#113405, RRID:AB_2206942) for $1 \mathrm{~h}$ at $4^{\circ} \mathrm{C}$. Cells were washed and resuspended in FACS buffer and then run on a BD FACSAria (BD Biosciences) and analyzed using FlowJo (TreeStar). All events were gated based on viable single cells, and data are reported as a percentage of the total viable single cell population unless otherwise noted (see In vivo monocyte depletion). Compensation and gating were performed using negative, single-stained, and isotype controls. Cell populations were gated as follows: $\mathrm{CD} 11 \mathrm{~b}^{+} \mathrm{Ly}_{6 \mathrm{G}}{ }^{+}$(neutrophils); F4/80 ${ }^{+} \mathrm{CD} 11 \mathrm{~b}^{+}$

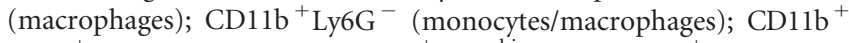
Ly6C $^{+}$Ly6G $^{-}$(monocytes); CD11b ${ }^{+}$Ly6C $^{\text {hi }} \mathrm{Ly}_{6 \mathrm{G}^{-}}$(CCR2 $^{+}$monocytes); CD11b ${ }^{+}$Ly6C $^{\text {lo }}$ Ly6G $^{-}$(CCR2 ${ }^{-}$monocytes); $75^{+}$(Schwann cells).

Myelin clearance. Myelin was visualized using Luxol fast blue (Electron Microscopy Sciences; catalog \#26681-01) on $20 \mu \mathrm{m}$ cryostat nerve sections following our previously published protocol (Niemi et al., 2013). Briefly, nerves were incubated in $\mathrm{H}_{2} \mathrm{O}, 35 \%$ and $70 \%$ ethanol for $5 \mathrm{~min}$ each, followed by incubation in $0.1 \%$ Luxol fast blue overnight at $60^{\circ} \mathrm{C}$. Nerves were subsequently destained in $0.05 \%$ lithium carbonate and incubated for 5 min each in increasing concentrations of ethanol (70\%/ $95 \% / 100 \%$ ), followed by xylenes before images were captured at $20 \times$ magnification under a light microscope. Positive myelin staining is expressed as a percentage of the total area examined. For the myelin clearance time course, each ipsilateral nerve is expressed as a percentage decrease over the contralateral nerve in the same animal.

ORO phagocytosis time course assay. Macrophages and Schwann cells were detected using CD11b and GFAP, respectively, using the IHC protocol described above. Nerve sections were subsequently incubated in $0.15 \% \mathrm{ORO} / \mathrm{H}_{2} \mathrm{O}$ solution for $20 \mathrm{~min}$ at room temperature to stain degenerated myelin and then washed in PBS. Cell counts were performed using $40 \times$ magnification on a fluorescence/light microscope by averaging the total number of cells in three nerve regions each measuring $200 \mu \mathrm{m} \times 150 \mu \mathrm{m}$. Phagocytic cells were counted based on the overlap of CD11b with ORO, or GFAP with ORO.

In vivo microsphere injection and cell phagocytosis assay. Immediately before transection, sciatic nerves were injected unilaterally with a total volume of $1 \mu \mathrm{l}$ fluorescent polystyrene microspheres (Fluoresbrite YG 

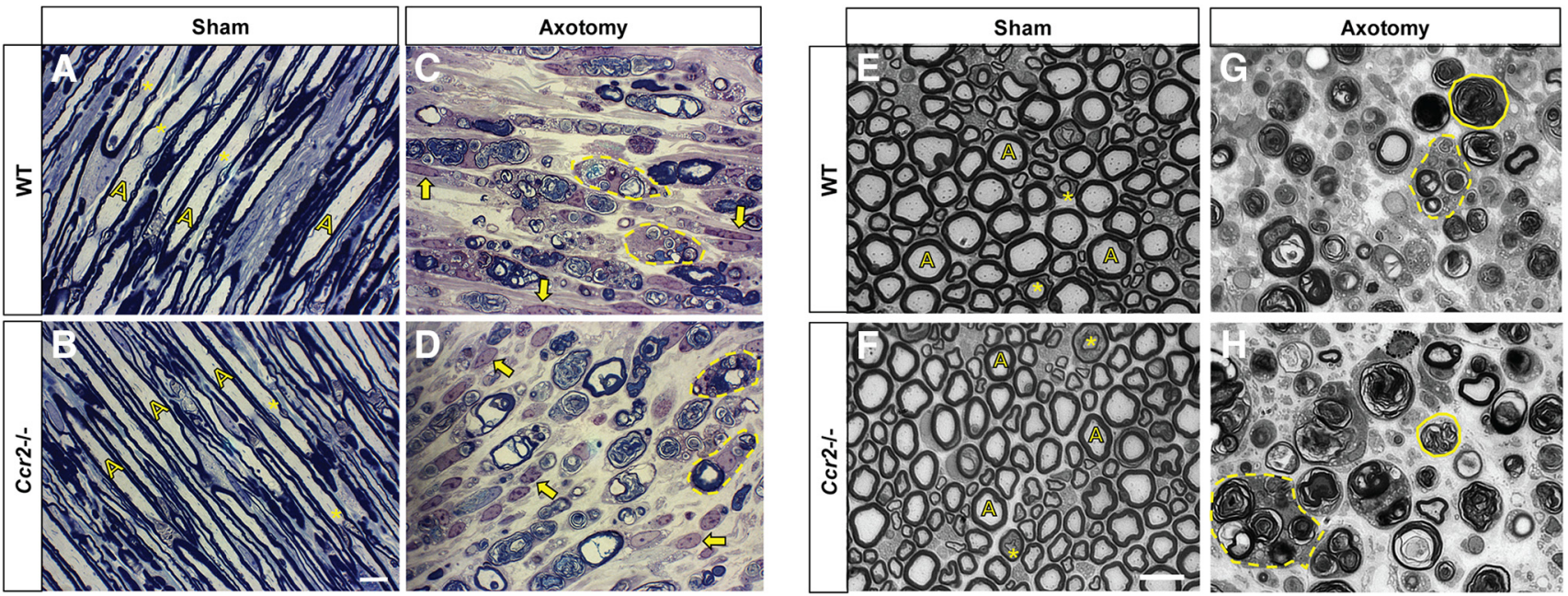

I

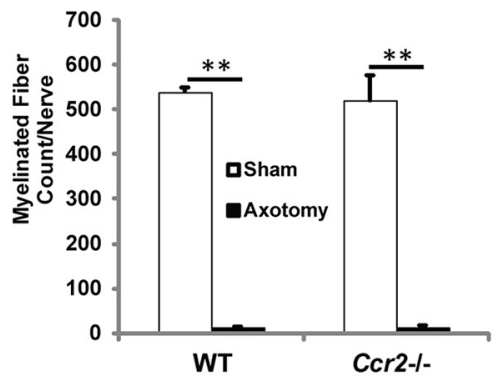

$\mathbf{J}$

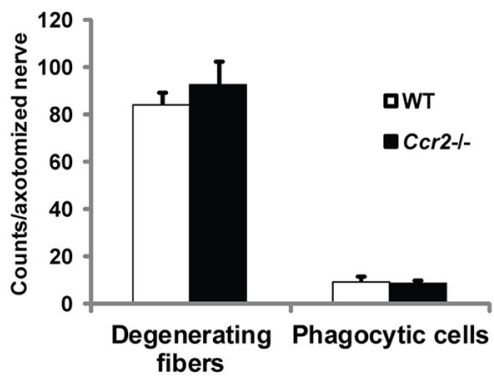

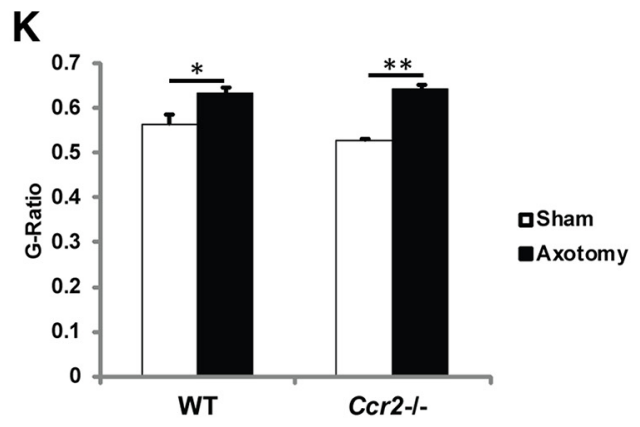

Neurofilament-light

Myelin Protein Zero

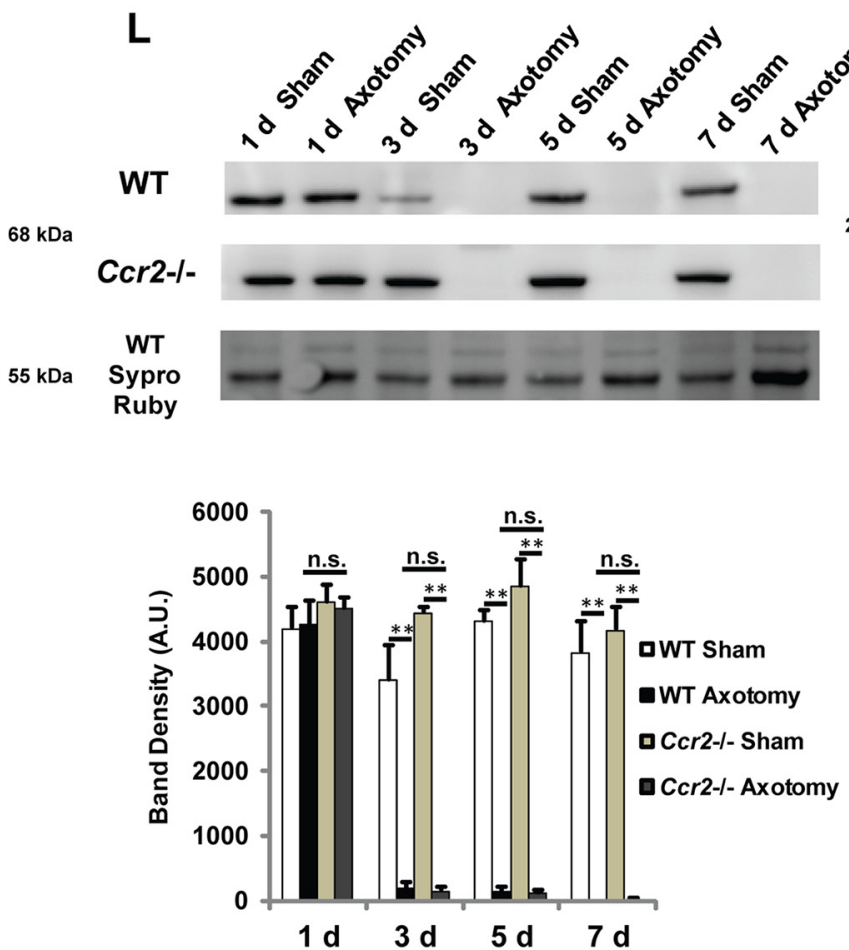

M

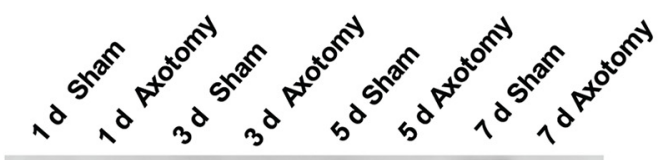

WT

$27 \mathrm{kDa}$

Ccr2-/-

Ccr2-I-
Sypro
Ruby

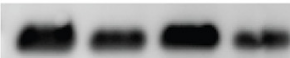

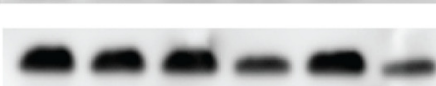
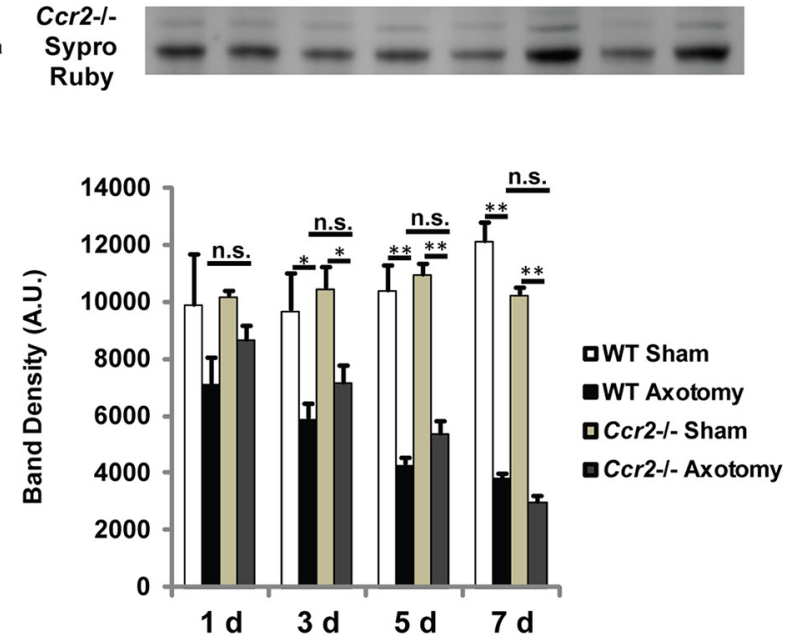

Figure 2. Axonal and myelin degeneration is comparable between WT and $\left(c r 2^{-1-}\right.$ mice. $\boldsymbol{A}-\boldsymbol{D}$, Longitudinal sciatic nerve semithin sections of contralateral $(\boldsymbol{A}, \boldsymbol{B})$ and $7 \mathrm{~d}$ axotomized $(\boldsymbol{C}, \boldsymbol{D})$ nerves of WT $(\boldsymbol{A}, \boldsymbol{C})$ and $C \mathrm{Cr} 2^{-1-}(\boldsymbol{B}, \boldsymbol{D})$ mice were stained with toluidine blue to visualize myelinated nerve fibers. Representative images of contralateral nerves show myelinated and intact individual axons (yellow A), and Schmidt-Lanterman clefts (asterisk). Injured nerves display a large number of nuclei (arrow) and phagocytic cells containing degenerating myelin profiles and lipid vacuoles (dotted line). Scale bar, $10 \mu \mathrm{m} . \boldsymbol{E}-\boldsymbol{H}$, Representative images of cross sections of contralateral $(\boldsymbol{E}, \boldsymbol{F})$ and axotomized $(\boldsymbol{G}, \boldsymbol{H})$ nerves of WT $(\boldsymbol{E}, \boldsymbol{G})$ and $\left(\boldsymbol{C r} 2^{-1-}(\boldsymbol{F}, \boldsymbol{H})\right.$ mice. Solid lines outline degenerating fibers. Dotted lines indicate phagocytic cells containing degenerating myelin profiles and lipid vacuoles. Scale bar, $10 \mu \mathrm{m}$. $\boldsymbol{I} \boldsymbol{K} \boldsymbol{K}$, No significant (Figure legend continues.) 
Microspheres, $2.00 \mu \mathrm{m}$, Polysciences, catalog \#18338-5). Injections were made using a 33 gauge needle attached to a Hamilton syringe at 3 sites of the nerve distal to the site to be injured to ensure that the microspheres pervade the nerve. Three and $7 \mathrm{~d}$ after injury/injection, nerves were harvested and prepared for flow cytometry as discussed previously. Phagocytic cells were sorted based upon their ingestion of the fluorescent microspheres, fixed in 4\% PFA, and labeled according to IHC protocol to detect macrophages, Schwann cells, neutrophils, dendritic cells, fibroblasts, and endothelial cells. Images were captured at $25 \times$ magnification, and cell counts were performed to determine the percentage phagocytic cells of the total phagocytic population. The phagocytic index was calculated by dividing the total number of microspheres ingested per cell type by the total number of phagocytic cells per cell type.

Tissue phagocytosis assay. Three and $7 \mathrm{~d}$ after injury, nerves were harvested and processed for IHC. Nerve sections were double-stained with MBP to label myelin, and CD68, p75, or Ly6G to label macrophages, Schwann cells, or neutrophils, respectively. Confocal images were captured at $40 \times$ magnification (Leica SP8) using Application Suite X software (Leica Biosystems). Cell counts were performed according to the previously described IHC protocol. Colocalization with MBP indicated phagocytosis. Only cells that were clearly associated with a nucleus were counted. The mean phagocytic cell percentage was calculated by dividing the total number of phagocytic cells per cell type by the total number of cells for that cell type.

In vivo neutrophil depletion. Neutrophil depletion was accomplished by intraperitoneal injection of $500 \mu \mathrm{g}$ InVivoPlus Ly6G antibody (1A8; BioXCell; catalog \#BP0075-1) at - 1, 0, and $2 \mathrm{~d}$ after injury. Control mice were injected with an IgG2a isotype control antibody. Depletion analysis was performed on blood and nerves at $3 \mathrm{~d}$ after injury using flow cytometry. After gating on viable single cells, the level of neutrophil depletion was confirmed in the blood by gating on $\mathrm{Ly} 6 \mathrm{G}^{+} \mathrm{CD} 11 \mathrm{~b}^{+} \mathrm{Ly} 6 \mathrm{C}^{+}$cells and $\mathrm{CD} 11 \mathrm{~b}^{+}$side scatter $^{\text {hi }}$ (SSC ${ }^{\text {hi }}$; indicates cell granularity) cells, and in the nerve by gating on $\mathrm{Ly}_{6 \mathrm{G}}{ }^{+} \mathrm{CD} 11 \mathrm{~b}{ }^{+} \mathrm{F} 4 / 80^{-}$cells.

In vivo monocyte depletion. WT and $\mathrm{C} \times 3 \mathrm{crl} 1^{-1-}$ mice were used for these experiments. Ly6C ${ }^{\text {hi }}$ CCR $2{ }^{+}$monocyte depletion was achieved by intraperitoneal injection of $20 \mu \mathrm{g}$ of a mouse monoclonal antibody against CCR2 (MC-21) (Mack et al., 2001; Brühl et al., 2007) in $100 \mu \mathrm{l}$ PBS at $1,2,3$, and $4 \mathrm{~d}$ after sciatic nerve transection. Injections commenced $1 \mathrm{~d}$ after injury to reduce the possibility of monocyte replenishment (Brühl et al., 2007). Control mice were similarly injected with an IgG2b isotype control antibody (MC-67) (Mack et al., 2001; Brühl et al., 2007). Blood was analyzed at $5 \mathrm{~d}$ after injury using flow cytometry to confirm depletion by gating on $\mathrm{CD} 11 \mathrm{~b}^{+} \mathrm{Ly}_{6 \mathrm{C}}{ }^{+} \mathrm{Ly} 6 \mathrm{G}^{-}$cells. The percentages of $\mathrm{Ly}_{6 \mathrm{C}} \mathrm{C}^{\text {in }}$ and $\mathrm{Ly} 6 \mathrm{C}^{\text {lo }}$ cells were analyzed within the CD11b ${ }^{+} \mathrm{Ly} 6 \mathrm{G}^{-}$ population.

qPCR. The expression of $C c l 2, C x 3 c l 1, C x c l 1$, and $C x c l 2$ was analyzed by RT-PCR. Six and $48 \mathrm{~h}$ after injury, sciatic nerves from WT and $\mathrm{Ccr} 2^{-1-}$ mice were flash frozen and RNA isolated from pairs of ipsilateral and contralateral nerves using Trizol (Invitrogen, catalog \#15596026). Four samples were included for both time points. Two pooled nerves were used for each sample. Total RNA was quantified, and $400 \mathrm{ng}$ was reverse transcribed using a High Capacity cDNA Reverse Transcription kit (Ap-

\footnotetext{
(Figure legend continued.) differences in number of myelinated fibers per nerve $(I)$, number of degenerating fibers and phagocytic cells $(\boldsymbol{J})$, or g-ratios $(\boldsymbol{K})$ were observed between injured $7 \mathrm{~d}$ WT and $C\left(\mathrm{Cr} 2^{-I-}\right.$ nerves. $I, n=4$ or 5 mice per genotype per time point. $F_{(1,17)}=486.65$, ${ }^{* *} p<0.001$ (ANOVA). J, No statistical significance. $\boldsymbol{K}, F_{(1,17)}=25.53,{ }^{*} p=0.039,{ }^{* *} p<$ 0.001 (ANOVA). $L, M$, Western blot analyses of neurofilament-light ( $\boldsymbol{L}$ ) and myelin protein zero $(M)$ in sciatic nerves with time after injury also show no significant differences between genotypes in the removal of axonal and myelin proteins, respectively. $L, n=3$ mice per genotype per time point. For $3 \mathrm{~d}, F_{(1,9)}=395.61,{ }^{* *} p<0.001$ (ANOVA); for $5 \mathrm{~d}, F_{(1,10)}=397.86,{ }^{* *} p<$ 0.001 (ANOVA); for $7 \mathrm{~d}, F_{(1,10)}=179.22,{ }^{* *} p<0.001$ (ANOVA). $M, n=3$ mice per genotype per time point. For $3 \mathrm{~d}, F_{(1,10)}=17.59,{ }^{*} p=0.014$ for WT, ${ }^{*} p=0.024$ for (cr $2^{-1-}$ (ANOVA); for $5 \mathrm{~d}, F_{(1,10)}=120.84,{ }^{* *} p<0.001$ (ANOVA); for $7 \mathrm{~d}, F_{(1,10)}=130.61,{ }^{* *} p<0.001$ (ANOVA). Differences in neurofilament-light and myelin protein zero in axotomized nerves between genotypes at individual time points were not statistically significant. Separate gels were run for each genotype, and both proteins were run on the same gel.
}

plied Biosystems, catalog \#4368814). RT-PCR was performed in an ABI Step-One Plus, using prevalidated TaqMan expression assays [Ccl2, Mm00441242_m1; Cx3cl1, Mm00436454_m1; Cxcl1, Mm04207460_ml; Cxcl2, Mm00436450_m1; glyceraldehyde-3-phosphate dehydrogenase (Gapdh), Mm99999915_g1; Applied Biosystems], and samples were assayed in triplicate. Relative expression was determined using the Comparative Ct Model $(\Delta \Delta \mathrm{Ct})$ with Gapdh as the internal control. Unlike with GAPDH protein levels, Gapdh mRNA levels do not change with axotomy in the sciatic nerve.

Experimental design and statistical analysis. Mice were randomly assigned to treatment groups for in vivo monocyte and neutrophil depletion experiments. Data in graphs are presented as mean \pm SEM. Full details of statistical analyses of each experiment can be found in the figure legends. For experiments involving multiple genotypes, treatments, and time points, a two-way ANOVA was performed, followed by a Tukey's post hoc test. For independent, two-group experiments, an unpaired Student's $t$ test (two-tailed) was used to determine statistical significance. Statistical analyses were performed using SigmaPlot version 12.3 (Systat Software, RRID:SCR_003210). Values were considered statistically significant at $p<0.05$. The number of experimental replicates $(n)$, the designation of $n$ belonging to the number of animals or cells, and experiment repetition are indicated in the figure legends. Data from all experiments were included in the analysis, with the exclusion of data that were outside the range of mean \pm 2 SDs. Data exclusion occurred in only one experiment and is described in the legend to Figure 12. Quantitative analyses, with the exception of flow cytometry, qPCR, and Western blotting, were performed with the experimenter blinded to genotype and experimental manipulation.

\section{Results}

\section{Wallerian degeneration in the $C c r 2^{-/-}$mouse}

We previously reported that myelin clearance in the $C \mathrm{cr} 2^{-1-}$ mouse is comparable with WT mice $7 \mathrm{~d}$ after sciatic nerve transection, despite a significant reduction in macrophage accumulation in the $C \mathrm{cr} 2^{-1-}$ nerve (Niemi et al., 2013). Here, a time course of Luxol fast blue, which binds to lipoproteins of the myelin sheath and is an easy and reliable method of measuring myelin clearance (Kluver and Barrera, 1953), was performed to more fully characterize WD in the mutant model. Gradual removal of myelin was observed in both WT and Ccr2 $2^{-1-}$ nerves over a period of $7 \mathrm{~d}$ (Fig. $1 A-C$ ), when examined at $0 \mathrm{~d}$ (Fig. $1 D, E), 1 \mathrm{~d}$ (Fig. $1 F, G$ ), $3 \mathrm{~d}$ (Fig. $1 H, I$ ), $5 \mathrm{~d}$ (Fig. $1 \mathrm{~J}, K$ ), and $7 \mathrm{~d}$ (Fig. $1 L, M$ ) after axotomy. Clearance began at $3 \mathrm{~d}$ after injury when monocyte-derived macrophages commence their egress from the blood (Hirata and Kawabuchi, 2002; Mueller et al., 2003), which lends support to prior work that suggested that hematogenous macrophages are necessary for myelin removal (e.g., Beuche and Friede, 1984).

However, a notable difference in the level of myelin clearance was observed at $3 \mathrm{~d}$ after injury, when significantly more myelin had been removed in the mutant nerve compared with the WT nerve (Fig. 1C, $H, I$ ). This deviation from the WT model of WD points to a probable time point at which to ascertain genotypespecific differences in the mechanism of myelin clearance.

A more thorough analysis of the nerve morphometry at $7 \mathrm{~d}$ after injury is provided by longitudinal sections of toluidine bluestained nerves (Fig. $2 A-D$ ). Normal myelination of axons was observed in sham-operated WT and mutant nerves (Fig. 2A,B), whereas a qualitatively comparable disruption and disappearance of myelin sheaths were apparent in both WT and Ccr2 $2^{-1-}$ injured nerves (Fig. 2C,D). Cross-sections of these sham and axotomized nerves (Fig. $2 E-H$ ) indicated that, between genotypes, there were an equivalent number of myelinated fibers both before injury and after injury (Fig. 2I), a similar number of degenerated fibers and phagocytic cells (Fig. $2 J$ ), and comparable g-ratio 

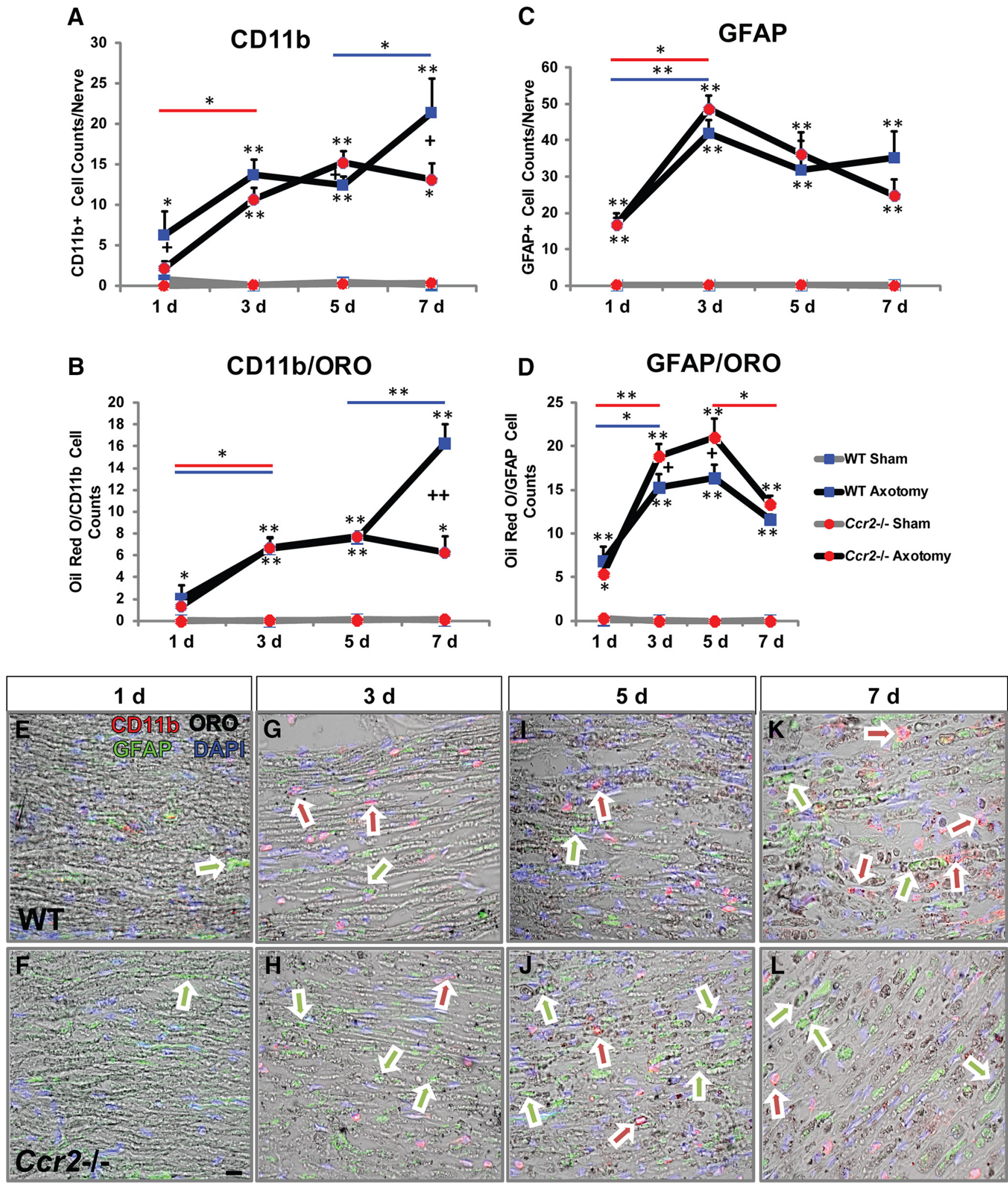

Figure 3. $C\left(\mathrm{Cr} 2^{-1-}\right.$ nerves boast more phagocytic Schwann cells than WT nerves. $\boldsymbol{A}-\boldsymbol{D}$, Injury time course shows $\mathrm{CD} 11 \mathrm{~b}^{+}$macrophages $(\boldsymbol{A})$, phagocytic macrophages $(\boldsymbol{B})$, GFAP ${ }^{+}$Schwann cells (C), and phagocytic Schwann cells (D). Phagocytic cells were determined based on the colocalization of ORO (black) with either CD11b (red) or GFAP (green). C(cr2 ${ }^{-1-}$ mice show increased uptake of degenerated myelin by Schwann cells at 3 and $5 \mathrm{~d}$ after sciatic nerve transection compared with WT mice. CD11b ${ }^{+}$populations are comparable between genotypes at 1,3 , and $5 \mathrm{~d}$ after injury but increase significantly between 5 and $7 \mathrm{~d}$ in WT nerves alone. $A, n=4$ or 5 mice per genotype per time point. Between injury at individual time points: at $1 \mathrm{~d}, F_{(1.16)}=8.38,{ }^{*} p=0.015$ for WT (ANOVA); at $3 \mathrm{~d}, F_{(1,18)}=106.8,{ }^{* *} p<0.001$ forWT and $\left(\mathrm{cr} 2^{-1-}\right.$ (ANOVA); at $5 \mathrm{~d}, F_{(1,16)}=214.79,{ }^{* *} p<0.001$ for WT and $\left(\mathrm{cr} 2^{-1-}\right.$ (ANOVA); at $7 \mathrm{~d}, F_{(1,18)}=54.55,{ }^{*} p=0.001$ for $C\left(\mathrm{cr} 2^{-1-}\right.$, ${ }^{* *} p<0.001$ for WT (ANOVA). Between genotypes at individual time points: at $1 \mathrm{~d}, F_{(1,16)}=3.48,{ }^{+} p=0.045$ (ANOVA); at $5 \mathrm{~d}, F_{(1,16)}=2.03,{ }^{+} p=0.047$ (ANOVA); at $7 \mathrm{~d}, F_{(1,18)}=3.05,{ }^{+} p=$ 0.022 (ANOVA). Between time points: 1 and $3 \mathrm{~d}, F_{(3,34)}=12.08,{ }^{*} p=0.043$ for $\left(\mathrm{Cr} 2^{-1-}\right.$ (ANOVA); 5 and $7 \mathrm{~d}, F_{(3,34)}=12.08,{ }^{*} p=0.043$ for WT (ANOVA). B, Between injury at individual time points: at $1 \mathrm{~d}, F_{(1,16)}=8.03,{ }^{*} p=0.039$ for WT (ANOVA); at $3 \mathrm{~d}, F_{(1,18)}=111.26,{ }^{* *} p<0.001$ for WT and $C\left(\mathrm{Cr} 2^{-1-}\right.$ (ANOVA); at $5 \mathrm{~d}, F_{(1,16)}=422.7,{ }^{* *} p<0.001$ for WT and C(Cr2 ${ }^{-l-}$ (ANOVA); at $7 \mathrm{~d}, F_{(1,18)}=97.2,{ }^{*} p=0.002$ for $\left(\mathrm{cr} 2^{-I-},{ }^{* *} p<0.001\right.$ for WT (ANOVA). Between genotypes at individual time points: at $7 \mathrm{~d}, F_{(1,18)}=19.23$, (Figure legend continues.) 
values (Fig. $2 \mathrm{~K}$ ). Significantly higher g-ratio values were observed for the remaining undisrupted myelin sheaths in both WT and $\mathrm{Ccr}^{-1-}$ mice after axotomy, which is an indication of thinner myelin sheaths.

We further characterized axonal and myelin degradation in WT and $C \mathrm{Cr} 2^{-1-}$ mice at various times after axotomy to identify any divergence in the mechanism of WD between these genotypes. After a nerve insult is made in the peripheral nervous system, the axons distal to the injury site undergo an intrinsic process of granular disintegration (George et al., 1995; Wang et al., 2012). Although axonal breakdown should not be affected by the loss of monocyte influx to the nerve in the $\mathrm{Cr} 2^{-1-}$ mouse, clearance of the debris is considered a macrophage function. We therefore probed for the axonal protein neurofilament-light at 1 , 3,5 , and $7 \mathrm{~d}$ after injury and observed complete disappearance of the protein by $3 \mathrm{~d}$ in both WT and mutant mice (Fig. $2 L$ ). A time course of removal of peripheral myelin protein zero was also similar between genotypes (Fig. $2 M$ ), further validating the idea that similarly efficient mechanisms of debris clearance occur in these mice, despite a notable decrease in macrophage accumulation in $\mathrm{Ccr}^{-1-}$ nerves (Niemi et al., 2013).

\section{Schwann cells play a role in the compensatory mechanism of myelin clearance in the $\mathrm{Crr}^{-1-}$ mouse}

No defect is seen in the clearance of axonal and myelin debris in the $\mathrm{Cr}^{-1-}$ mouse, and we interpret these results to mean that there are compensatory actions by one or more phagocytes to remove the distal nerve fragments in the absence of CCR2 ${ }^{+}$macrophages. Of the potential candidates for this compensatory mechanism, we initially focused on Schwann cells because there have been extensive reports on the phagocytic activity of these cells during WD (e.g., Bigbee et al., 1987; Stoll et al., 1989). Using ORO to label metabolized myelin (e.g., Boivin et al., 2007), we identified phagocytosing GFAP ${ }^{+}$Schwann cells and CD11b ${ }^{+}$ macrophages in injured nerve sections at $1,3,5$, and $7 \mathrm{~d}$ after axotomy (Fig. 3E-L). It is important to note that, although we used CD11b to identify macrophages, neutrophils are very likely included in this population at 1 and $3 \mathrm{~d}$ after injury. Total cell counts of macrophages (Fig. $3 A$ ) and macrophages colocalized with ORO (Fig. 3B) indicated that, although both injured WT and $\mathrm{Ccr}^{-1-}$ nerves demonstrated an increase in the number of phagocytosing macrophages over their respective sham-operated nerves, WT nerves exhibited a significant increase in the number of phagocytic macrophages over mutant nerves between 5 and $7 \mathrm{~d}$ after injury. Schwann cell counts were comparable between ge-

$\leftarrow$

(Figure legend continued.) ${ }^{++} p<0.001$ (ANOVA). Between time points: 1 and $3 \mathrm{~d}, F_{(3,34)}=$ $26.58,{ }^{*} p=0.031$ for WT, ${ }^{*} p=0.005$ for $\left(\mathrm{Cr} 2^{-1-} ; 5\right.$ and $7 \mathrm{~d}, F_{(3,34)}=26.58,{ }^{* *} p<0.001$ for WT. C, Between injury at individual time points: at $1 \mathrm{~d}, F_{(1,16)}=76.83,{ }^{* *} p<0.001$ for WT and $C\left(\mathrm{Cr} 2^{-1-}\right.$ (ANOVA); at $3 \mathrm{~d}, F_{(1,18)}=298.0,{ }^{* *} p<0.001$ for WT and $\left(\mathrm{Cr} 2^{-1-}\right.$ (ANOVA); at $5 \mathrm{~d}, F_{(1,16)}=48.66,{ }^{* *} p<0.001$ forWT and $\left(\mathrm{Cr} 2^{-1-}\right.$ (ANOVA); at $7 \mathrm{~d}, F_{(1,18)}=50.68,{ }^{* *} p<$ 0.001 for WT and $\left(\mathrm{Cr} 2^{-1-}\right.$ (ANOVA). Between time points: 1 and $3 \mathrm{~d}, F_{(3,34)}=10.61,{ }^{*} p=$ 0.010 for WT, ${ }^{* *} p<0.001$ for $\left(\mathrm{Cr} 2^{-1-}\right.$ (ANOVA). D, Between injury at individual time points: at $1 \mathrm{~d}, F_{(1,16)}=33.93,{ }^{*} p=0.002$ for $\left(\mathrm{cr} 2^{-1-},{ }^{* *} p<0.001\right.$ for WT (ANOVA); at $3 \mathrm{~d}, F_{(1,18)}=$ 267.49, ${ }^{* *} p<0.001$ for WT and C(cr2 ${ }^{-1-}$ (ANOVA); at $5 \mathrm{~d}, F_{(1,16)}=196.0,{ }^{* *} p<0.001$ for WT and $\left(\mathrm{cr} 2^{-1-}\right.$ (ANOVA); at $7 \mathrm{~d}, F_{(1,18)}=493.39,^{* *} p<0.001$ for WT and $\mathrm{Cr}^{-1-}$ (ANOVA). Between genotypes at individual time points: at $3 \mathrm{~d}, F_{(1,18)}=2.75,{ }^{+} p=0.029$ (ANOVA); at $5 \mathrm{~d}, F_{(1,16)}=3.01,{ }^{+} p=0.028$ (ANOVA); at $7 \mathrm{~d}, F_{(1,18)}=2.03, p=0.052$, not significant. Between time points: 1 and $3 \mathrm{~d}, F_{(3,34)}=30.05,{ }^{*} p=0.002$ forWT, ${ }^{* *} p<0.001$ for

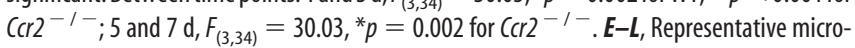
graphs of CD11b, GFAP and ORO at $1 \mathrm{~d}(\boldsymbol{E}, \boldsymbol{F}), 3 \mathrm{~d}(\boldsymbol{G}, \boldsymbol{H}), 5 \mathrm{~d}(\boldsymbol{I}, \boldsymbol{J})$, and $7 \mathrm{~d}(\boldsymbol{K}, \boldsymbol{L})$ after injury in WT $(\boldsymbol{E}, \boldsymbol{G}, \boldsymbol{I}, \boldsymbol{K})$ and $\left(\mathrm{Cr} 2^{-1-}(\boldsymbol{F}, \boldsymbol{H}, \boldsymbol{J}, \boldsymbol{L})\right.$ nerves. Arrows indicate CD11b/ORO (red/black) overlap and GFAP/ORO (green/black) overlap. Scale bar, $20 \mu \mathrm{m}$. notypes at all time points (Fig. 3C). However, more phagocytic Schwann cells in $C c r 2^{-1-}$ nerves were identified at 3 and $5 \mathrm{~d}$ after injury (Fig. 3D). This small but significant increase in the number of phagocytosing Schwann cells in mutant nerves over WT nerves suggests that Schwann cells are part of the compensatory mechanism of WD in $\mathrm{Crr} 2^{-1-}$ mice.

\section{Cellular analysis of the $\mathrm{Crr} 2^{-/-}$sciatic nerve}

To ascertain how a substantial reduction in macrophage accumulation after injury fails to inhibit myelin clearance in the $\mathrm{Ccr} 2^{-1-}$ mouse, we identified changes in the cellular composition of the injured sciatic nerve in these mutant mice. Immunohistochemical analysis showed that the number of $\mathrm{CD} 68^{+}$macrophages in the nerve was significantly reduced in $\mathrm{Ccr}^{-1-}$ mice at $3 \mathrm{~d}$ compared with WT mice (Fig. $4 A, B, E$ ), with both genotypes exhibiting a significant increase between 3 and $7 \mathrm{~d}$ after injury. In line with previous findings (Siebert et al., 2000; Niemi et al., 2013), macrophage accumulation in $C c r 2^{-1-}$ nerves was also significantly attenuated $7 \mathrm{~d}$ after injury compared with WT nerves (Fig. $4 C-E$ ). The Schwann cell population was also analyzed; and similar to cell counts performed in the ORO assay (Fig. 3C), no significant differences in the number of $\mathrm{GFAP}^{+}$cells were identified between genotypes at either time point (Fig. 4E).

Flow cytometric analyses were also performed to assess further differences in cell populations between WT and $\mathrm{Cr} 2^{-1-}$ nerves after injury. As expected, sciatic nerve axotomy stimulated a greater accumulation of macrophages $\left(\mathrm{CD} 11 \mathrm{~b}^{+} \mathrm{F} 4 / 80^{+}\right.$and $\left.\mathrm{CD} 11 \mathrm{~b}^{+} \mathrm{Ly}_{6 \mathrm{G}}{ }^{-}\right)$in WT nerves than in $\mathrm{Ccr} 2^{-1-}$ nerves at both 3 and $7 \mathrm{~d}$ after injury (Fig. $4 F, H, I$ ). The percentage of $\mathrm{p} 75^{+}$ Schwann cells was comparable between genotypes at both time points (Fig. $4 J$ ). Axotomy induced an increase in $\mathrm{p} 75^{+}$cells after $7 \mathrm{~d}$ in WT nerves and after 3 and $7 \mathrm{~d}$ in $\mathrm{Ccr} 2^{-1-}$ nerves. More neutrophils $\left(\mathrm{CD} 11 \mathrm{~b}^{+} \mathrm{Ly}_{6 \mathrm{G}}{ }^{+}\right)$for both genotypes were observed at $3 \mathrm{~d}$ after injury compared with $7 \mathrm{~d}$ (Fig. $4 G, K$ ). We have found that neutrophils accumulate within the entire distal stump, not merely at the injury site (Fig. 5A,B). This finding is in line with previous work that identified the multilobed nuclei of neutrophils along the entire sciatic nerve distal stump through $4 \mathrm{~d}$ after a crush injury, with a peak accumulation after $1 \mathrm{~d}$ (Nadeau et al., 2011).

Remarkably, injury induced a significantly larger influx of neutrophils in $\mathrm{Ccr} 2^{-1-}$ nerves at $3 \mathrm{~d}$ after injury compared with WT nerves (Fig. $4 G, K$ ). Somewhat similarly, in a previous report, a compensatory increase in neutrophil infiltration into the brain was seen in $\mathrm{Ccr} 2^{\mathrm{RFP} / \mathrm{RFP}}$ (i.e., $\mathrm{Ccr}^{-1-}$ ) mice in a model of experimental autoimmune encephalomyelitis (Saederup et al., 2010). Furthermore, we and others have shown that $\mathrm{Crr} 2^{-1-}$ mice boast a higher percentage of blood neutrophils relative to WT mice under both noninflammatory and inflammatory conditions (see Fig. $11 B-E$ ) (Dunay et al., 2010), which could explain the increased accumulation in the nerve $3 \mathrm{~d}$ after injury. This time point of significantly higher accumulation of neutrophils, which are well known for their phagocytic activity (Soehnlein and Lindbom, 2010), correlates with increased myelin clearance in the $\mathrm{Ccr} 2^{-/-}$ nerve (Fig. 1C, $H, I$ ). Aside from the well-characterized reduction in macrophages after injury in $\mathrm{Cr} 2^{-1-}$ mice compared with WT mice, the elevated neutrophil infiltration in $\mathrm{Ccr}^{-1-}$ nerves is the one difference we have observed in the cellular makeup of the nerves between these two genotypes. 

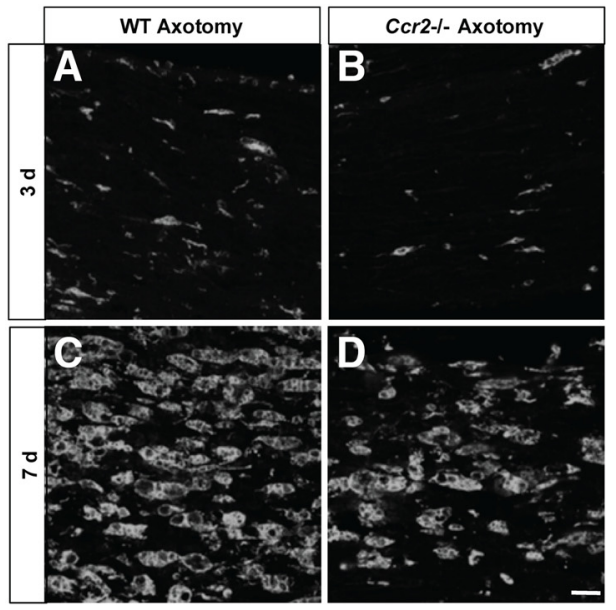

F
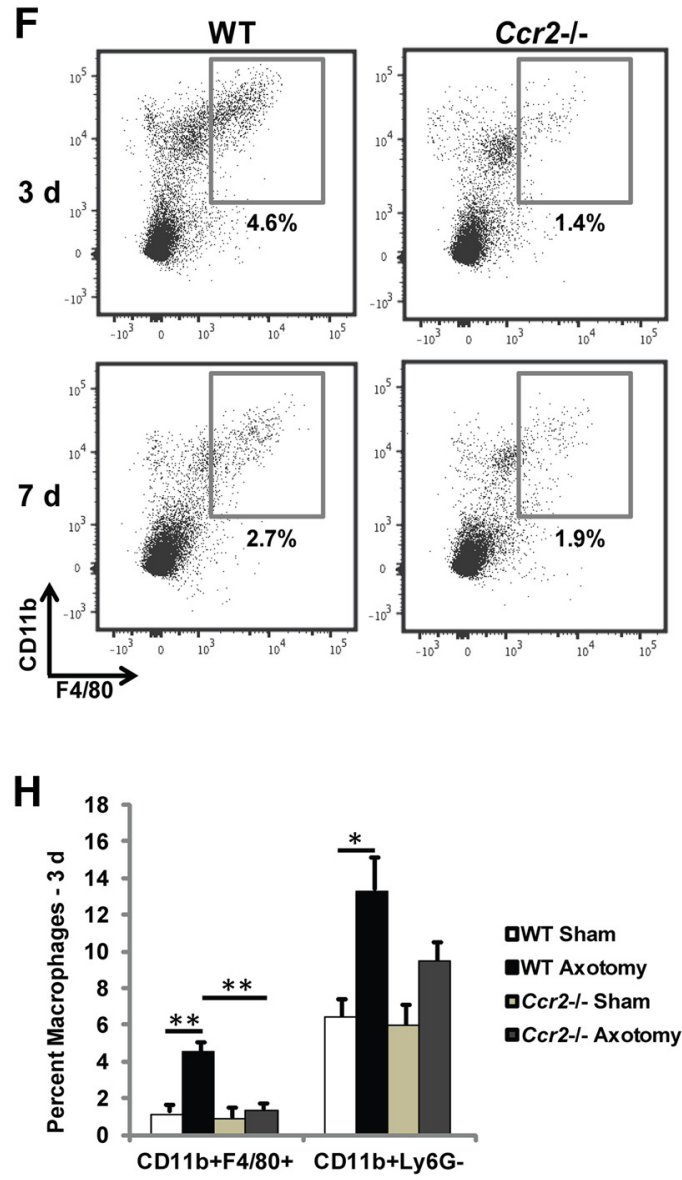

DWT Sham

WT Axotomy

口Ccr2-I-Sham

aCcr2-I- Axotomy

\section{J}

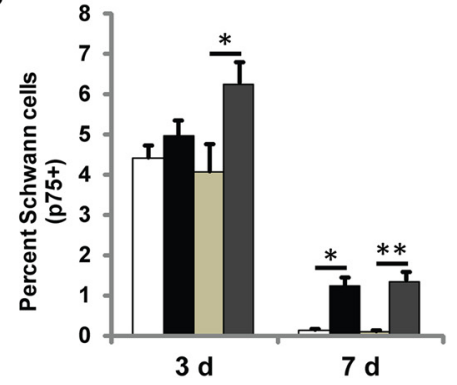

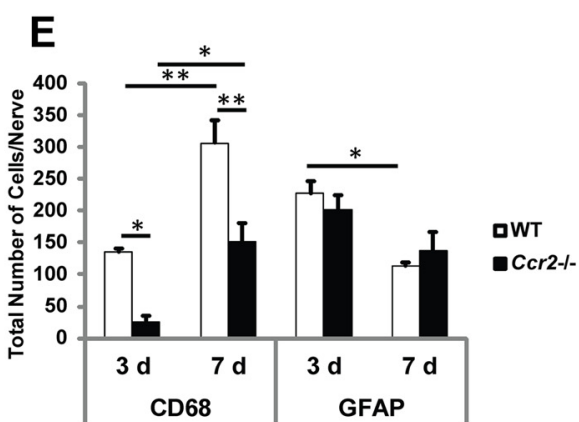

G
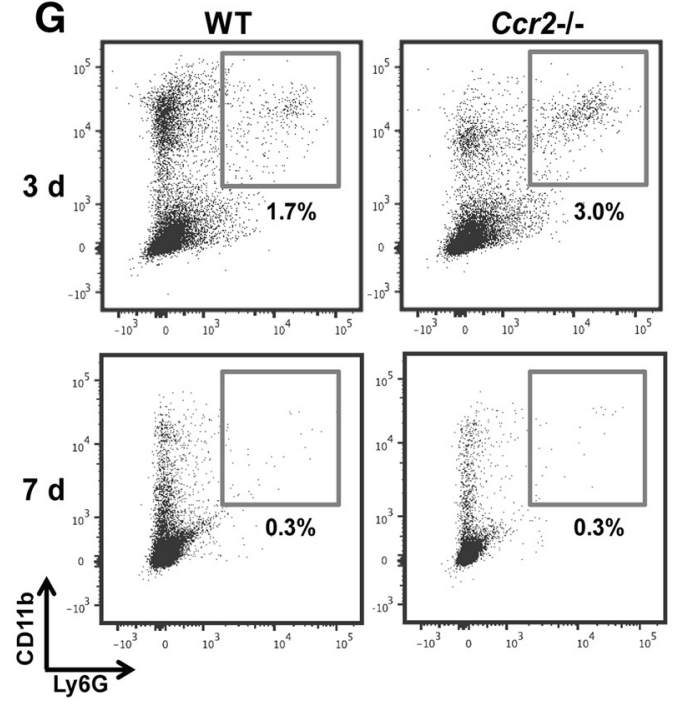

I

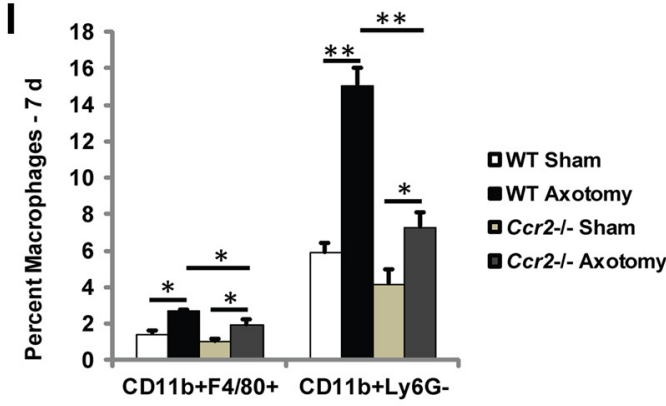

K

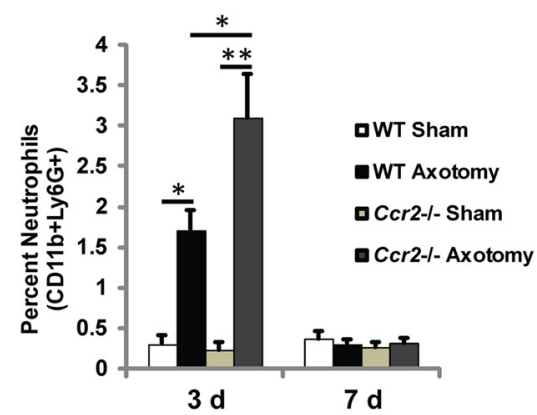

Figure 4. Macrophage accumulation is significantly diminished and neutrophil accumulation is significantly increased in the injured sciatic nerves of C ${ }^{2}{ }^{-} /-$mice, compared with WT mice. Three and $7 \mathrm{~d}$ after transection, the distal nerve segments were dissected and examined using IHC or flow cytometry. $\boldsymbol{A}-\boldsymbol{D}$, Representative images show that accumulation of CD68 ${ }^{+}$macrophages is significantly reduced in axotomized $\left(\mathrm{cr} 2^{-1-}\right.$ nerves at 3 and $7 \mathrm{~d}$ after injury $(\boldsymbol{B}, \boldsymbol{D})$ compared with WT nerves $(\boldsymbol{A}, \boldsymbol{C})$. Scale bar, $10 \mu \mathrm{m}$. $\boldsymbol{E}, \mathbf{Q}$ uantification of total (Figure legend continues.) 
A

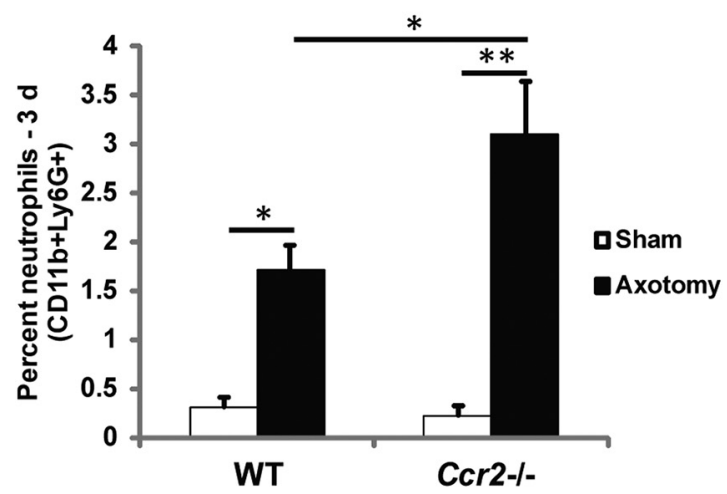

B Distal Stump - Injury Site $(2 \mathrm{~mm})$

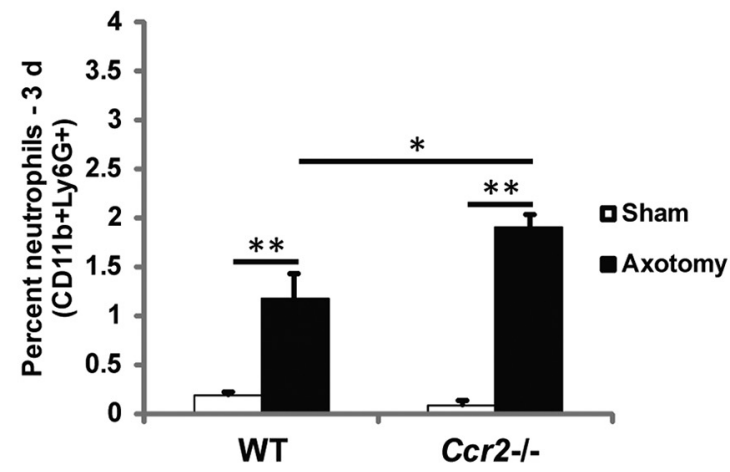

Figure 5. Neutrophils accumulate along the length of the injured distal sciatic nerve, not just at the injury site. $A, B$, Flow cytometric analysis of neutrophil populations (CD11b ${ }^{+}$Ly $\left.6 \mathrm{G}^{+}\right)$in $3 \mathrm{~d}$ injured nerves that include the injury site $(\boldsymbol{A})$ and exclude the injury site $(\boldsymbol{B})$ indicates that neutrophils accumulate within the entire distal stump and not merely at the site of injury. Similar to nerves that include the injury site, significantly more neutrophils accumulate in injured $\left(\mathrm{Cr} 2^{-1-}\right.$ nerves compared with WT nerves when the injury site is excluded. "Distal Stump-Injury Site (2 mm)" indicates that a $2 \mathrm{~mm}$ segment of nerve that included the injury site was removed before processing for flow cytometry. $A, n=3$ mice per genotype. Between injury: $F_{(1,10)}=49.54,{ }^{*} p=0.011$ for WT, ${ }^{* *} p<0.001$ for (Cr2 ${ }^{-1-}$ (ANOVA). Between genotypes: $F_{(1,10)}=4.56,{ }^{*} p=0.013$ (ANOVA). $B, n=4$ mice per genotype. Between injury: $F_{(1,14)}=91.31,{ }^{* *} p<0.001$ (ANOVA). Between genotypes: $F_{(1,14)}=4.66,{ }^{*} p=0.004$ (ANOVA).

Regulation of transcript levels of neutrophil and macrophage chemokines in the sciatic nerve after injury

A possible explanation of the increase in neutrophils in the sciatic nerves of $\mathrm{Ccr} 2^{-1-}$ mice would be that it simply is the result of the increase in blood neutrophils. Another possibility is that it reflects a difference in the expression of neutrophil chemokines. CXCL1 (KC/GRO) and CXCL2 (MIP-2) are neutrophil chemoattractants that are released by resident macrophages during inflammation and show increased expression in injured mouse sciatic nerves within $1 \mathrm{~d}$ after injury (Soehnlein and Lindbom, 2010; Nadeau et al., 2011). Here, sciatic nerves were assayed at 6 and $48 \mathrm{~h}$ after transection. Cxcl1 and Cxcl2 mRNA in shamoperated nerves were negligible at both time points, whereas large increases in Cxcl1 and Cxcl2 mRNA were measured in both WT and $\mathrm{Ccr} 2^{-1-}$ axotomized nerves at $6 \mathrm{~h}$ after injury (Fig. 6A). Notably, high expression of $\mathrm{Cxcl} 1$ and $\mathrm{Cxcl} 2 \mathrm{mRNA}$ was maintained $48 \mathrm{~h}$ after injury in $C \mathrm{cr} 2^{-1-}$ nerves alone (Fig. $6 \mathrm{~B}$ ). These data suggest that sustained increases in neutrophil chemokine

$\leftarrow$

(Figure legend continued.) $\mathrm{CD}{ }^{+}{ }^{+}$and GFAP ${ }^{+}$cell counts indicates that macrophage numbers are significantly reduced in $\mathrm{Ccr}^{-1-}$ nerves compared with WT nerves at both time points after injury, whereas Schwann cell numbers are comparable between genotypes at both time points. $n=5$ mice per genotype per time point. For $\mathrm{CD} 68$ between genotypes: $F_{(1,18)}=29.71$, ${ }^{*} p=0.006,{ }^{* *} p<0.001$ (ANOVA). For CD68 between time points: $F_{(1,18)}=37.39,{ }^{*} p=$ $0.002,{ }^{* *} p<0.001$ (ANOVA). For GFAP between time points: $F_{(1,18)}=16.8,{ }^{*} p=0.002$ (ANOVA). $\boldsymbol{F}-\boldsymbol{K}$, Flow cytometric analysis of macrophage populations $(\boldsymbol{F})$ in injured nerves confirms the significant attenuation of $\mathrm{CD} 11 \mathrm{~b}^{+} \mathrm{F} 4 / 80^{+}$and $\mathrm{CD} 11 \mathrm{~b}^{+} \mathrm{Ly6G}^{-}$cells in $\mathrm{C} \mathrm{Cr} 2^{-1-}$ mice at both $3 \mathrm{~d}(\boldsymbol{H})$ and $7 \mathrm{~d}(\boldsymbol{I})$ after injury. $\boldsymbol{H}$, For $C D 11 b^{+} \mathrm{F} 4 / 80^{+}$: between injury: $n=3$ mice per genotype, $F_{(1,10)}=19.82,{ }^{* *} p<0.001$; between genotypes: $F_{(1,10)}=16.31$, ${ }^{* *} p<0.001$ (ANOVA). For CD11b ${ }^{+}$Ly6G $^{-}$: between injury: $F_{(1,10)}=18.2,{ }^{*} p=0.004$ (ANOVA). $I$, For $\mathrm{CD} 11 \mathrm{~b}^{+} \mathrm{F} 4 / 80^{+}$: between injury: $n=3$ mice per genotype, $F_{(1,10)}=30.03,{ }^{*} p=0.002$ for WT, ${ }^{*} p=0.012$ for $\left(\mathrm{Cr} 2^{-1-}\right.$ (ANOVA); between genotypes: $F_{(1,10)}=9.55,{ }^{*} p=0.023$ (ANOVA). For CD11b ${ }^{+}$Ly6G $^{-}$: between injury: $F_{(1,10)}=62.9,{ }^{* *} p<0.001$ for WT, ${ }^{*} p=0.021$ for $\left(\mathrm{Cr} 2^{-1-}\right.$ (ANOVA); between genotypes: $F_{(1,10)}=37.27,{ }^{* *} p<0.001$ (ANOVA). J, Similar to $\mathrm{IHC}$ results, $\mathrm{p} 75^{+}$Schwann cells were comparable between genotypes at both time points. For $3 \mathrm{~d}, F_{(1,10)}=7.82,{ }^{*} p=0.014$ (ANOVA); for $7 \mathrm{~d}, F_{(1,10)}=61.14,{ }^{*} p=0.001$ for WT, ${ }^{* *} p<$ 0.001 for C(Cr2 ${ }^{-I-}$ (ANOVA). G, $K$, Strikingly, CD11b ${ }^{+}$Ly6G ${ }^{+}$neutrophils were more prevalent in $\mathrm{Cr}^{-1-}$ nerves $3 \mathrm{~d}$ after axotomy compared with WT nerves. Between injury: $F_{(1,10)}=$ $49.54,{ }^{*} p=0.011$ for WT, ${ }^{* *} p<0.001$ for (Cr2 ${ }^{-1-}$ (ANOVA). Between genotypes: $F_{(1,10)}=$ $4.56,{ }^{*} p=0.013$ (ANOVA). expression in $\mathrm{Ccr} 2^{-1-}$ nerves may be the major cause for the larger neutrophil accumulation observed $3 \mathrm{~d}$ after injury.

In addition to the surge in neutrophil infiltration, axotomy induces an increase in macrophage numbers in $\mathrm{Ccr}^{-1-}$ mice despite a significantly reduced accumulation compared with WT mice (Fig. 4E). An interesting possibility is that, in the absence of $\mathrm{CCR} 2{ }^{+}$macrophage accumulation, other populations of CCR2 ${ }^{-}$ monocytes enter the injured nerve via an alternative receptor chemotactic response, such as CX3CL1 binding to CX3CR1 (Imai et al., 1997). However, we observed negligible expression of Cx3cll mRNA at 6 and $48 \mathrm{~h}$ in axotomized nerves for both genotypes (Fig. $6 C, D)$. Ccl2 expression in WT nerves was slightly higher at $6 \mathrm{~h}$ after axotomy than in nerves from $\mathrm{Ccr} 2^{-1-}$ mice, but the levels in both genotypes were comparable at $48 \mathrm{~h}$.

\section{Conditional inhibition of CCR2 displays comparable} macrophage accumulation and myelin clearance to global Ccr $2^{-1-}$ mice after nerve injury

Previous work has shown that macrophage depletion critically retards nerve debris clearance (Brück et al., 1996; Dailey et al., 1998; Liu et al., 2000; Barrette et al., 2008). It is important to note, however, that none of these studies used global knock-outs wherein macrophage function was affected throughout the lifespan of the rodent. Rather, macrophage recruitment and activity were affected temporally and/or spatially, using genetic models or pharmacological agents. Our laboratory significantly inhibited macrophage accumulation in the global $\mathrm{Ccr} 2^{-1-}$ model with no hindering effect on debris clearance, which suggests that, in the absence of CCR $2{ }^{+}$monocytes, other cells were successfully compensating for the loss. Could this compensation be attributed to the constitutive loss of CCR2 throughout development?

We sought to answer this question by conditionally inhibiting CCR2. WT mice were treated with an anti-CCR2 antibody MC-21 or an isotype control antibody MC-67 (Mack et al., 2001) for $4 \mathrm{~d}$ starting $1 \mathrm{~d}$ after nerve transection (Fig. $7 A$ ). Nerves were analyzed at $5 \mathrm{~d}$ after injury rather than at $7 \mathrm{~d}$ due to a prior report of the reappearance of monocytes less than a week after the initial treatment (Brühl et al., 2007). The total Ly6C ${ }^{+}$monocyte population $\left(\mathrm{CD} 11 \mathrm{~b}{ }^{+} \mathrm{Ly}_{6 \mathrm{C}}{ }^{+} \mathrm{Ly}_{6 \mathrm{G}}{ }^{-}\right)$was significantly reduced in the blood of mice treated with MC-21 compared with MC-67, with 
A

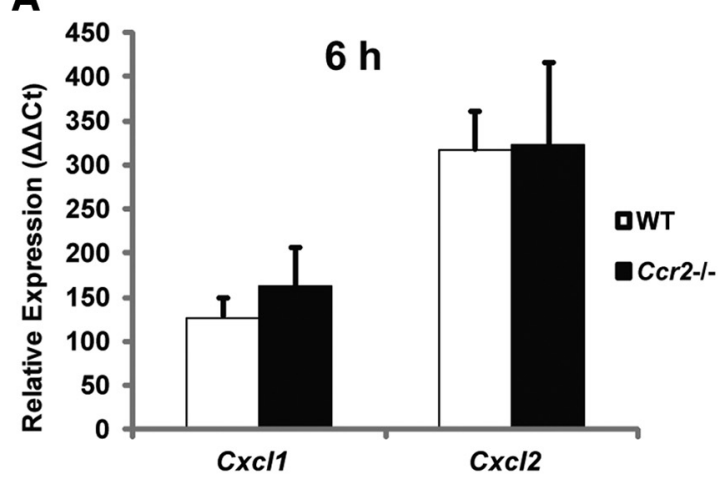

\section{C}

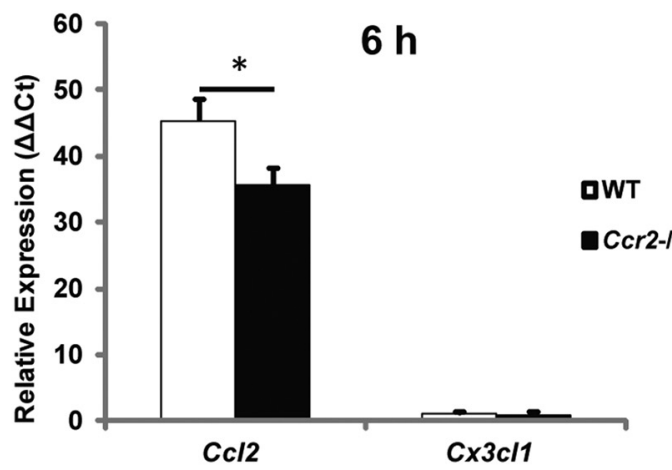

B

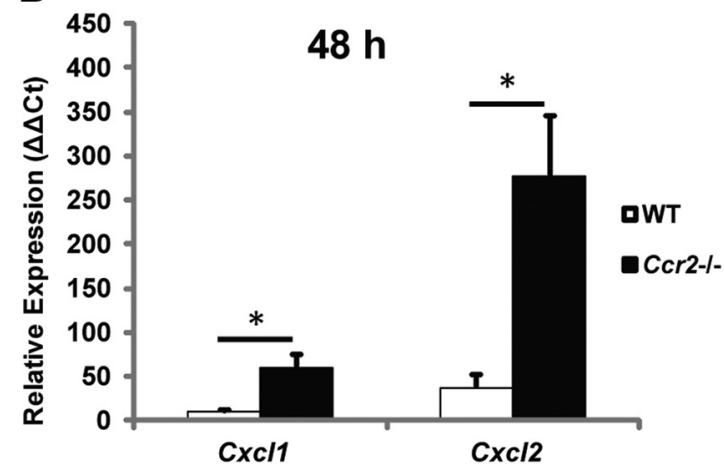

D

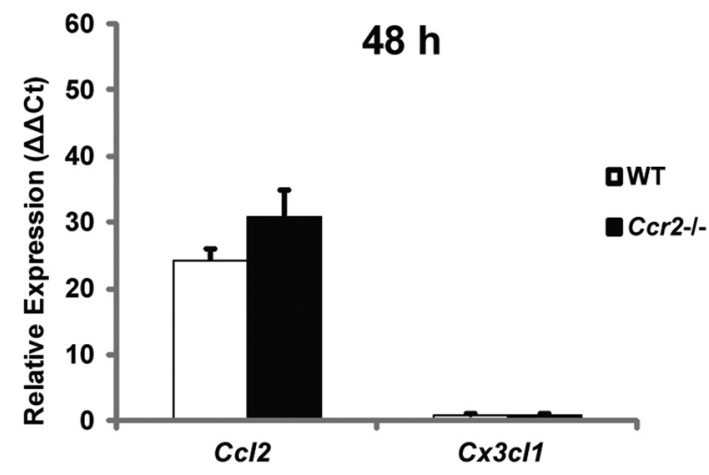

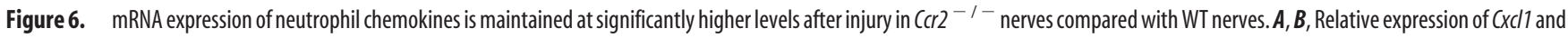
$\boldsymbol{C} \mathrm{x} / 2$ at $6 \mathrm{~h}(\boldsymbol{A})$ and $48 \mathrm{~h}(\boldsymbol{B})$ after sciatic nerve transection was quantified using the comparative $\mathrm{Ct}$ method ( $\Delta \Delta \mathrm{Ct}$ ) normalized to the housekeeping gene Gapdh. Comparable expression between genotypes was observed $6 \mathrm{~h}$ after injury; however, expression was maintained only in $\left(\mathrm{Cr} 2^{-l}{ }^{-}\right.$nerves at $48 \mathrm{~h} . n=4$ samples per genotype (two nerves pooled per sample), $t_{(6)}=-3.51,{ }^{*} p=$ 0.0126 for $C x c 11$ (two-tailed $t$ test), $t_{(6)}=-3.46,{ }^{*} p=0.0134$ for $(x c / 2$ (two-tailed $t$ test). C, D, Gene expression of the macrophage chemokines $(\mathrm{cl} 2$ and $(x 3 \mathrm{cl} 1 \mathrm{was}$ also quantified at $6 \mathrm{~h}$ (C) and $48 \mathrm{~h}(\boldsymbol{D})$ after injury in WT and $\left(\mathrm{Cr} 2^{-\prime-}\right.$ nerves. $t_{(6)}=2.46,{ }^{*} p=0.0485$ (two-tailed $t$ test).

inflammatory Ly6C ${ }^{\text {hi }}\left(\mathrm{CCR}^{+}\right)$monocytes being specifically depleted (Fig. $7 B-D$ ). Blood neutrophil populations were unchanged by MC-21 treatment (Fig. 7E).

Further evidence of the importance of CCR2 in mediating monocyte extravasation from the blood was confirmed by measuring macrophage accumulation in the nerve. The percentage of $\mathrm{CD}{ }^{+}$macrophages in $\mathrm{MC}-21$-treated mice was comparable with that of global $\mathrm{Ccr} 2^{-1-}$ mice at $5 \mathrm{~d}$ after injury, both of which were significantly lower than MC-67-treated control mice (Fig. $7 F-I$ ). To determine whether the compensatory mechanism of WD in the global $\mathrm{Ccr} 2^{-1-}$ mouse is a result of the constitutive loss of CCR2, we analyzed myelin clearance in the nerves using Luxol fast blue. Interestingly, conditional blockade of CCR2 had no consequence on debris clearance at $5 \mathrm{~d}$ after injury (Fig. 7J$M)$. Also, similar to the increase in neutrophil accumulation in global $\mathrm{Cr} 2^{-1-}$ distal nerves over WT nerves $3 \mathrm{~d}$ after injury (Fig. $4 G, K)$, MC-21-treated nerves displayed a comparable significant increase in neutrophil accumulation over MC-67-treated nerves $3 \mathrm{~d}$ after injury (Fig. $7 \mathrm{~N}, \mathrm{O}$ ). This evidence suggests that the efficiency of WD in the global $C c r 2^{-1-}$ mouse is not the result of a compensatory developmental response to the loss of the CCR2 receptor.

Debris is cleared by a combination of phagocytes in the Ccr $2^{-1-}$ mouse

We have indicated that Schwann cells are contributing to the compensatory removal of myelin in the $\mathrm{Crr} 2^{-1-}$ mouse (Fig. 3). Nevertheless, the effect that we observed with Schwann cells may not be sufficient to account for the complete efficiency of myelin clearance in the $C c r 2^{-1-}$ nerve. Therefore, we expanded the search for potential phagocytes and assayed phagocytosis by additional cell types with reported phagocytic activity, including non-CCR2 ${ }^{+}$macrophages (Auffray et al., 2009), neutrophils (Soehnlein and Lindbom, 2010), dendritic cells (Savina and Amigorena, 2007), fibroblasts (Hall et al., 1994), and endothelial cells (Gao et al., 2013).

Phagocytosis was measured by the cellular uptake of fluorescentlabeled polystyrene microspheres (Savage et al., 2015) that were injected into the sciatic nerve immediately before axotomy. Phagocytic cells were sorted based on their ingestion of the beads, and the cells were then identified by immunocytochemistry. When expressed as a percentage of the total phagocytic population (Fig. 8A), macrophages in WT mice represent $62.0 \pm 10.5 \%$ of the phagocytes at $7 \mathrm{~d}$, and $39.4 \pm 1.1 \%$ at $3 \mathrm{~d}$. As expected, phagocytic macrophages in mutant nerves were drastically reduced compared with WT nerves, albeit a significant increase in the percentage of phagocytic macrophages was observed between $3 \mathrm{~d}(11.4 \pm 1.2 \%)$ and $7 \mathrm{~d}(28.4 \pm 7.8 \%)$ after axotomy.

Where the differences in the phagocytic cell populations between genotypes are most striking are the twofold increase in neutrophils in $\mathrm{Ccr} 2^{-1-}$ mice at $3 \mathrm{~d}(60.5 \pm 6.6 \%$, compared with $31.3 \pm 0.6 \%$ in WT mice), and the substantial increase in Schwann cells between 3 and $7 \mathrm{~d}$ in $\mathrm{Ccr} 2^{-1-}$ mice alone. There was a small but significant increase in phagocytic dendritic cells in WT nerves between time points and compared with $\mathrm{Ccr} 2^{-1-}$ nerves at $7 \mathrm{~d}$ (Fig. 8A). No changes were observed in fibroblasts or endothelial cells. Total cell counts are also represented and correspond appropriately with percentage data (Fig. 8B). These de- 


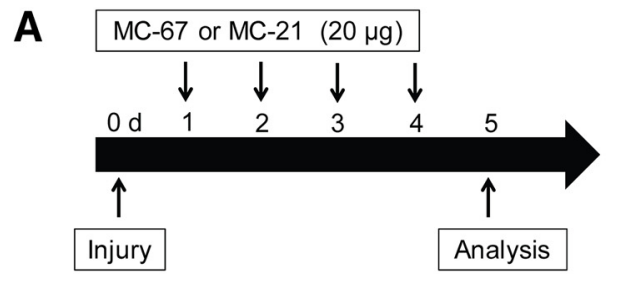

D

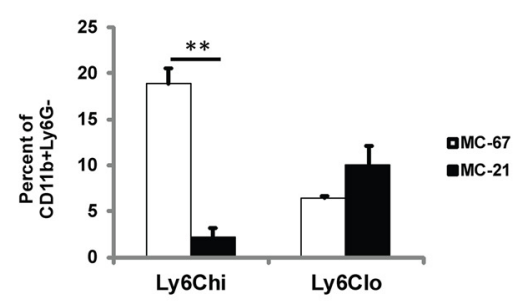

E

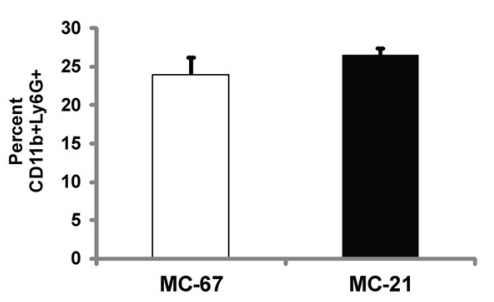

J
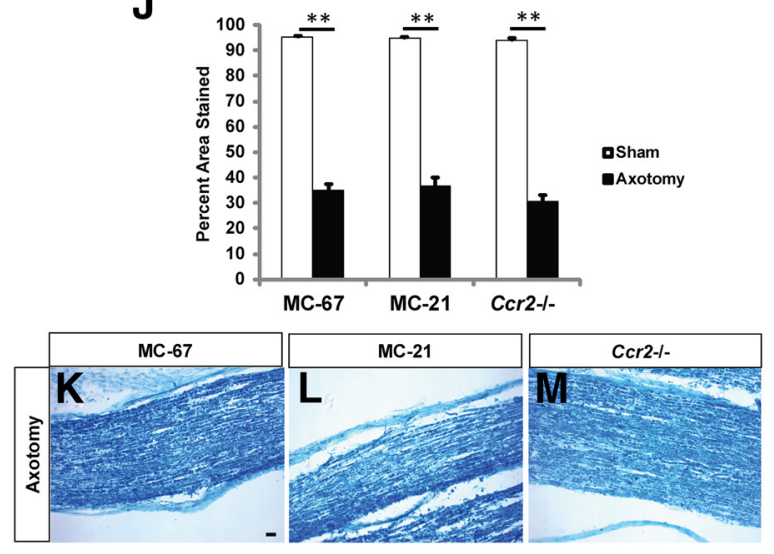

B

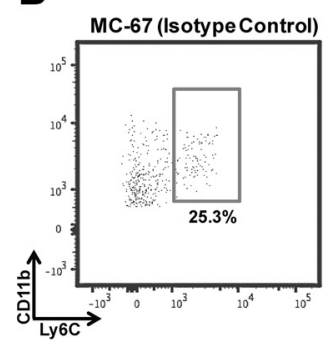

Blood

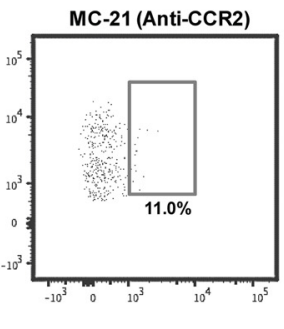

C

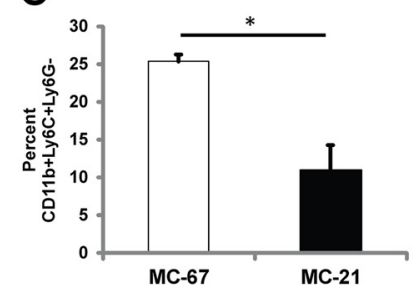

F
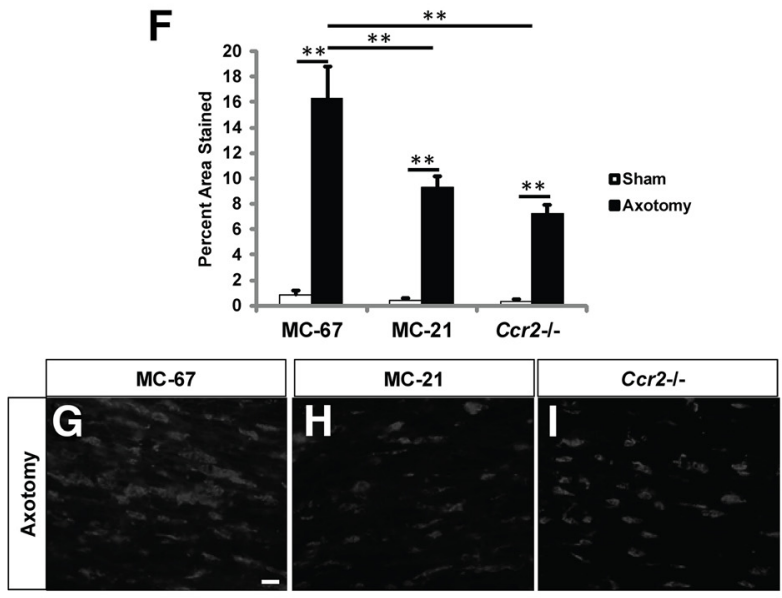

N

Nerve
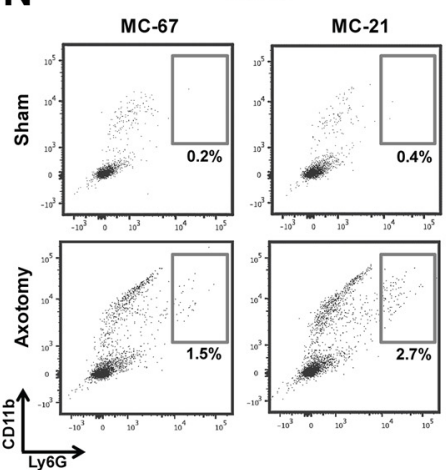

0

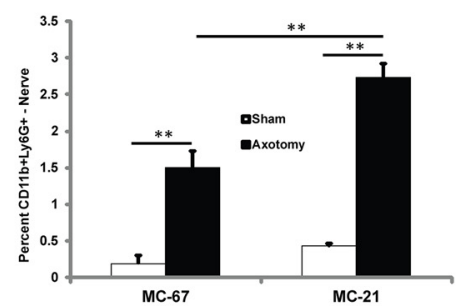

Figure 7. Conditional inhibition of CCR2 displays comparable neutrophil and macrophage accumulation in the distal sciatic nerve, and myelin clearance, compared with nerves of global $C\left(\mathrm{Cr} 2^{-1-}\right.$ mice. $A$, WT mice were treated with the anti-CCR2 depletion antibody MC-21 every day after injury for $4 \mathrm{~d}$, and analysis was performed on the fifth day. $\boldsymbol{B}-\boldsymbol{E}, \mathrm{MC}-21$ treatment significantly reduced the total Ly6C ${ }^{+}$monocyte population $(B, C)$ in the blood. $n=3$ mice per condition, $t_{(4)}=4.19,{ }^{*} p=0.0137$ (two-tailed $t$ test). $\boldsymbol{D}$, Inflammatory Ly6C hi monocytes were specifically depleted with MC-21 treatment. $t_{(4)}=9.46,{ }^{*} p<0.001$ (two-tailed $t$ test). No differences were observed in CD11b $^{+}$Ly6G ${ }^{+}$blood neutrophils $(\boldsymbol{E})$. $\boldsymbol{F}$, Accumulation of macrophages in sciatic nerves is represented as a percentage of the section area that was stained. $n=5$ mice per condition per genotype. Between injury: $F_{(1,28)}=130.12,{ }^{* *} p<0.001$ (ANOVA). Between conditions: $F_{(2,27)}=$ $10.13,{ }^{* *} p<0.001$ (ANOVA). $\mathbf{G}-\boldsymbol{I}$, Representative images of conditional inhibition of CCR2 $(\boldsymbol{H})$ and a global knock-out of (Cr2 (I) showed comparable reductions in CD68 ${ }^{+}$macrophage accumulation in injured nerves compared with MC-67 isotype control nerves (G). Scale bar, $20 \mu \mathrm{m}$. J-M, Quantification of myelin clearance using Luxol fast blue ( $)$ in MC-67-treated (K), MC-21-treated (L), or global C(C2 ${ }^{-1-}$ mice $(\boldsymbol{M})$ showed comparable removal of debris between all conditions $5 \mathrm{~d}$ after injury. $n=4$ or 5 mice per condition per genotype. Between injury: $F_{(1,26)}=1453.59,{ }^{* *} p<0.001$ (ANOVA). Scale bar, $20 \mu \mathrm{m} . \mathbf{N}, \mathbf{0}$, Similar to global C(r2 ${ }^{-1-}$ nerves (in Fig. 4), conditional inhibition of CCR2 produced significantly more CD11b ${ }^{+}$Ly6G ${ }^{+}$ neutrophils in the injured nerve compared with injured control nerves at $3 \mathrm{~d}$ after injury. $n=3$ mice per condition. Between injury: $F_{(1,10)}=131.05$, ${ }^{* *} p<0.001$ (ANOVA). Between conditions, $F_{(1,10)}=21.75,{ }^{* *} p<0.001$ (ANOVA).

viations between genotypes suggest that several different cell types, including neutrophils, Schwann cells, and non-CCR2 ${ }^{+}$macrophages, mediate debris clearance in $\mathrm{Ccr} 2^{-1-}$ mice when monocyte infiltration is inhibited. The finding of a major, compensatory role for neutrophils in the early removal of debris in the context of peripheral nerve injury is a particularly unexpected discovery.

We also considered the possibility that, in addition to any changes in the number and identity of the phagocytes between genotypes, perhaps the phagocytic capability of the cells in $\mathrm{Ccr} 2^{-1-}$ nerves increased in response to the loss of inflammatory macrophages. The microspheres proved useful in calculating a cell's phagocytic index, or the number of microspheres ingested per cell type, due to the ease of visualizing individual microspheres (Fig. $8 \mathrm{C}-\mathrm{H}$ ). At both 3 and $7 \mathrm{~d}$ after injury, there were no evident differences in the phagocytic indices of a particular cell type between WT and Ccr2 $2^{-I-}$ mice (Fig. $8 I-K$ ). However, we 
A

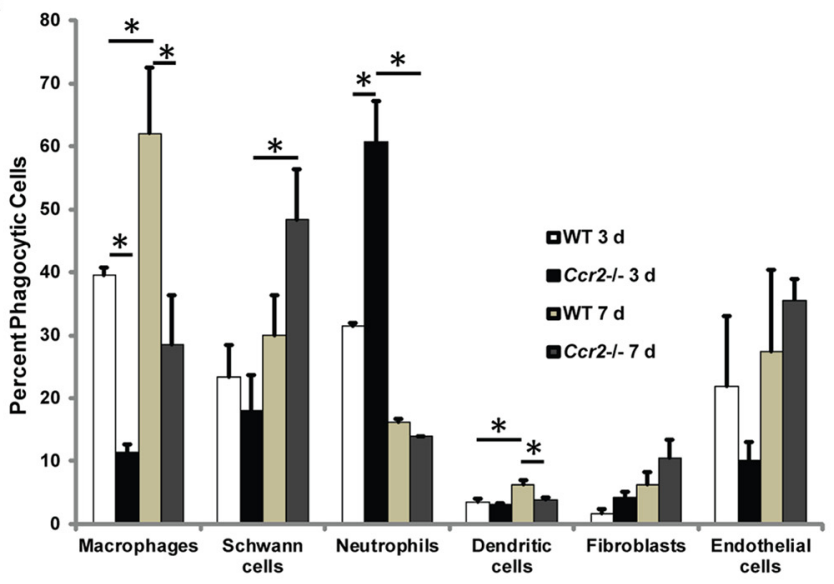

B

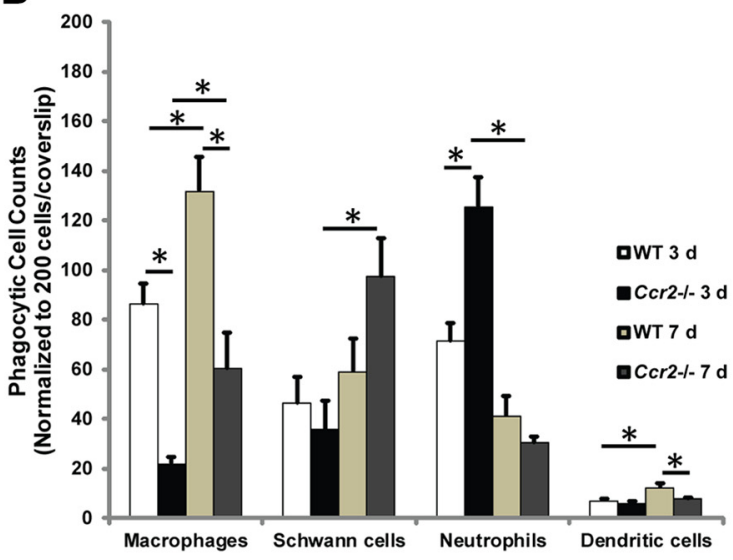

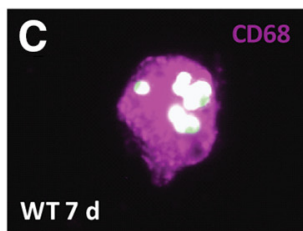
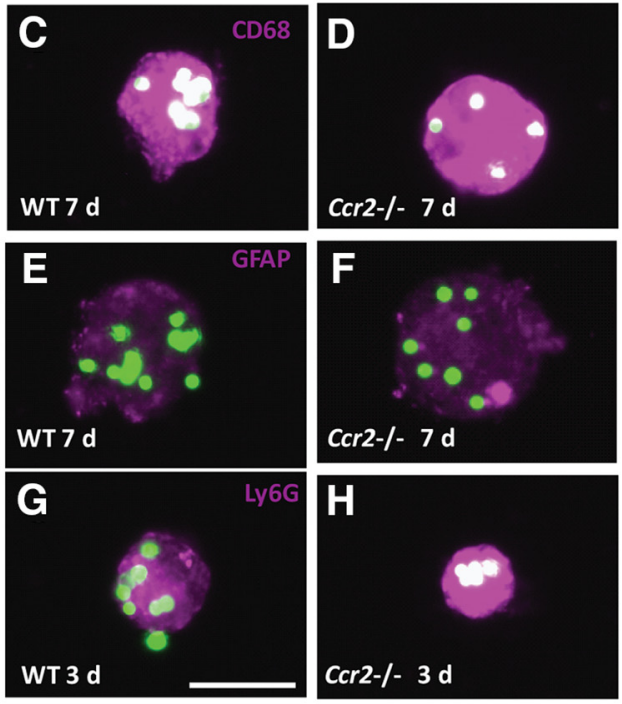

J

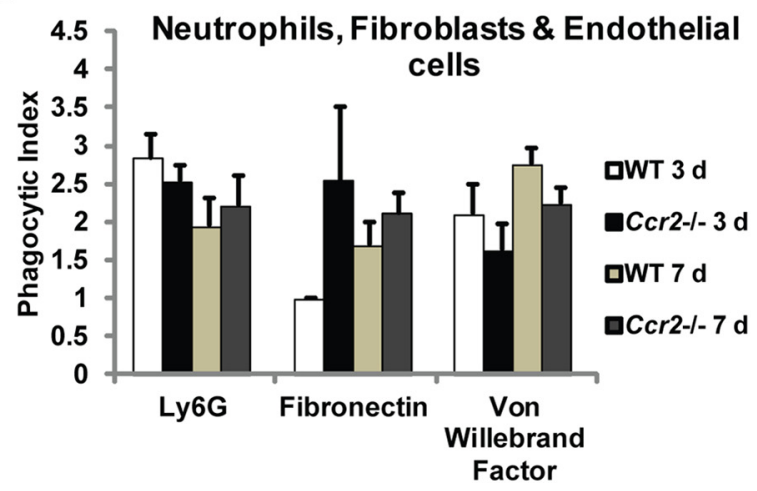

I

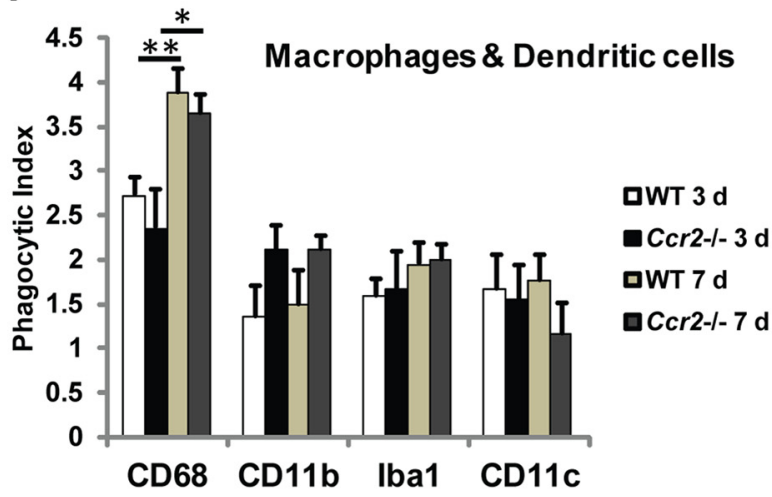

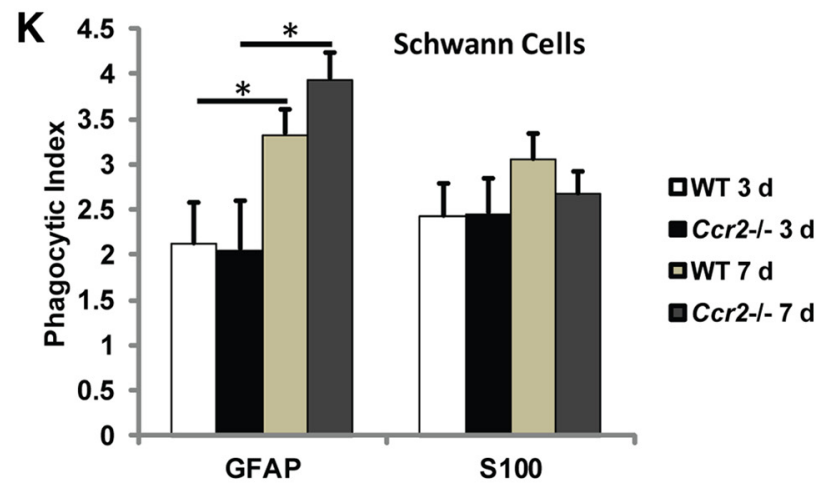

Figure 8. Significantly more neutrophils in $\mathrm{Ccr}^{-1-}$ nerves phagocytose polystyrene beads compared with WT nerves. $\boldsymbol{A}$, Fluorescent polystyrene beads were injected into sciatic nerves before injury, and phagocytic cells were sorted based on their ingestion of beads. Quantification of the percentage of total phagocytic cells shows differences between genotypes and time points in the phagocytosis of beads by CD68 ${ }^{+}$macrophages, GFAP ${ }^{+}$Schwann cells, Ly6G ${ }^{+}$neutrophils, and CD11c ${ }^{+}$dendritic cells, whereas no differences were observed in fibroblasts or endothelial cells. Significantly more phagocytic neutrophils are identified in the $\left(\mathrm{cr} 2^{-1-}\right.$ mouse at $3 \mathrm{~d}$ after injury compared with WT. This compensatory mechanism is also supplemented by an increase in phagocytosis by Schwann cells in C $\mathrm{cr} 2^{-1-}$ mice at $7 \mathrm{~d}$ after injury compared with its $3 \mathrm{~d}$ time point. Data are represented as an average of two or three independent experiments. $n=9-664$ phagocytic cells per cellular marker per experiment. For macrophages, between genotypes: $F_{(1,10)}=21.54,{ }^{*} p=0.018$ at $3 \mathrm{~d},{ }^{*} p=0.007$ at $7 \mathrm{~d}\left(\right.$ ANOVA); between time points: $F_{(1,10)}=8.9,{ }^{*} p=$ 0.043 (ANOVA). For Schwann cells, $F_{(1,10)}=8.23,{ }^{*} p=0.010$ (ANOVA). For neutrophils, between genotypes: $F_{(1,6)}=11.01,{ }^{*} p=0.007\left(\right.$ ANOVA); between time points: $F_{(1,6)}=57.67,{ }^{*} p=0.001$ (ANOVA). For dendritic cells, between genotypes: $F_{(1,6)}=9.93,{ }^{*} p=0.02$ (ANOVA); between time points: $F_{(1,6)}=16.04,{ }^{*} p=0.012$ (ANOVA). $B$, Cell counts were normalized to 200 cells per coverslip to allow for comparison of total number of phagocytic cells. Data are represented as an average of two or three independent experiments. $n=9-664$ phagocytic cells per cellular marker per experiment. For macrophages, between genotypes: $F_{(1,10)}=40.18,{ }^{*} p=0.003$ at $3 \mathrm{~d},{ }^{*} p=0.002$ at $7 \mathrm{~d}\left(\right.$ ANOVA); between time points: $F_{(1,10)}=15.45,{ }^{*} p=0.017$ for WT, ${ }^{*} p=0.035$ for Ccr2 ${ }^{-1-}$ (ANOVA). For Schwann cells, $F_{(1,10)}=8.54,{ }^{*} p=0.009$ (ANOVA). For neutrophils, between genotypes: $F_{(1,6)}=7.21,{ }^{*} p=0.009\left(\right.$ ANOVA); between time points: $F_{(1,6)}=60.76,{ }^{*} p=$ 0.001 (ANOVA). For dendritic cells, between genotypes: $F_{(1,6)}=9.93,{ }^{*} p=0.02$ (ANOVA); between time points: $F_{(1,6)}=16.04,{ }^{*} p=0.012($ ANOVA). $\boldsymbol{C}-\boldsymbol{K}$, Changes in cell phagocytic index are not responsible for the compensatory mechanism of nerve debris clearance in the $C_{\left(\mathrm{C} 2^{-/-}\right.}$mouse. $\mathbf{C}-\boldsymbol{H}$, Representative micrographs of phagocytic $\mathrm{CD}^{+} 8^{+}$(Figure legend continues.) 

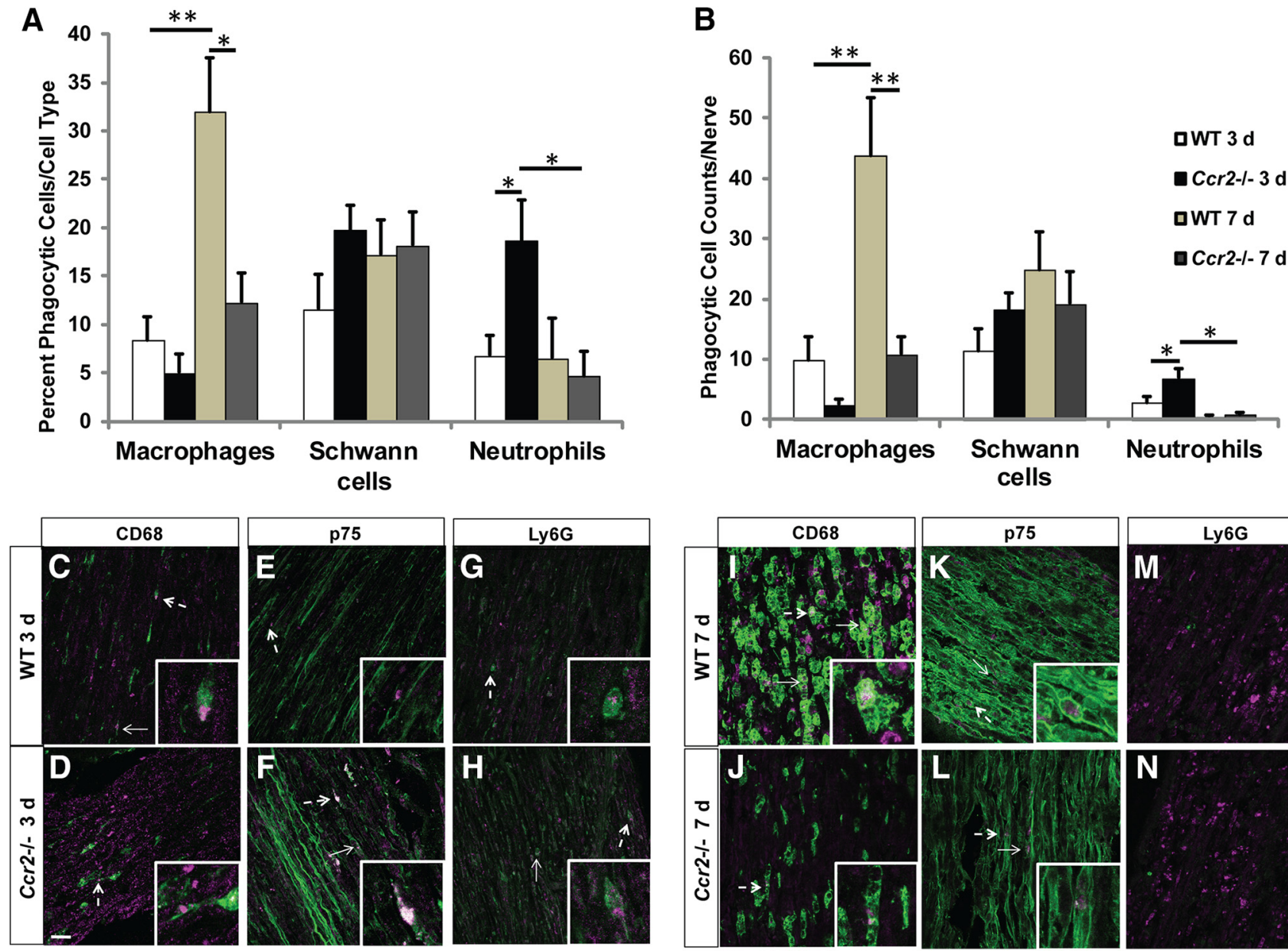

Figure 9. Significantly more macrophages phagocytose myelin in WT nerves $7 \mathrm{~d}$ after injury, whereas significantly more neutrophils phagocytose myelin in $C\left(\mathrm{Cr} 2^{-1-}\right.$ nerves $3 \mathrm{~d}$ after axotomy $\boldsymbol{A}, \boldsymbol{B}$, The percentage $(\boldsymbol{A})$ and number $(\boldsymbol{B})$ of phagocytic cells per cell type were quantified per genotype per time point. $\boldsymbol{A}$, For macrophages, $n=5$ mice per genotype per time point: between genotypes: $F_{(1,18)}=10.57,{ }^{*} p=0.001$ (ANOVA); between time points: $F_{(1,18)}=18.93,{ }^{* *} p<0.001$ (ANOVA). For Schwann cells, $n=5$ mice per genotype per time point, no statistical significance. For neutrophils, $n=5$ or 6 mice per genotype per time point: between genotypes: $F_{(1,19)}=2.05,{ }^{*} p=0.026$ (ANOVA); between time points: $F_{(1,19)}=4.11,{ }^{*} p=0.011$ (ANOVA). $B$, For macrophages, $n=5$ mice per genotype per time point: between genotypes: $F_{(1,18)}=14.17,{ }^{* *} p<0.001$ (ANOVA); between time points: $F_{(1.18)}=15.6,{ }^{* *} p<0.001$ (ANOVA). For Schwann cells, $n=5$ mice per genotype per time point, no statistical significance. For neutrophils, $n=5$ or 6 mice per genotype per time point: between genotypes: $F_{(1,19)}=4.12,{ }^{*} p=0.016($ (ANOVA); between time points: $F_{(1,19)}=14.92,{ }^{*} p=0.001$ (ANOVA). $\mathbf{C}-\boldsymbol{N}$, Representative images showing MBP and CD68 (C, $\left.\boldsymbol{D}, \boldsymbol{I}, \boldsymbol{J}\right), \mathrm{MBP}$ and $p 75(\boldsymbol{E}, \boldsymbol{F}, \boldsymbol{K}, \boldsymbol{L})$, and $M B P$ and $L y 6 G(\boldsymbol{G}, \boldsymbol{H}, \boldsymbol{M}, \boldsymbol{N})$ double labeling in the sciatic nerve $3 \mathrm{~d}(\boldsymbol{C}-\boldsymbol{H})$ or $7 \mathrm{~d}(\boldsymbol{I}-\boldsymbol{N})$ after a transection injury in WT $(\boldsymbol{C}, \boldsymbol{E}, \boldsymbol{G}, \boldsymbol{I}, \boldsymbol{K}, \boldsymbol{M})$ and $\left(\mathrm{Cr} 2^{-1-}(\boldsymbol{D}, \boldsymbol{F}, \boldsymbol{H}, \boldsymbol{J}, \boldsymbol{L}, \boldsymbol{N})\right.$ mice. Phagocytosis was determined by the colocalization of MBP (red) with $(D 68$, p75, or Ly6G (green) to label macrophages, Schwann cells, or neutrophils, respectively, in sciatic nerve tissue sections. Arrows indicate phagocytic cells. Dashed arrows indicate higher-magnification inset images. MBP immunofluorescence intensity $(\boldsymbol{C} \boldsymbol{H})$ and p75 immunofluorescence intensity $(\boldsymbol{E}, \boldsymbol{F})$ were altered after acquisition to allow for better visualization of the myelin stain. Any adjustments were applied comparably to each image. Scale bar, $10 \mu \mathrm{m}$.

observed significant increases in the phagocytic indices of $\mathrm{CD}^{+} 8^{+}$macrophages (Fig. 8I) and GFAP ${ }^{+}$Schwann cells (Fig. $8 K$ ) between 3 and $7 \mathrm{~d}$ after injury for both genotypes. This increase in phagocytic index could be attributed to cells ingesting more microspheres over time.

To specifically demonstrate phagocytosis of myelin debris, a complementary phagocytosis assay was performed using nerve

(Figure legend continued.) macrophages $(\boldsymbol{C}, \boldsymbol{D}), \mathrm{GFAP}^{+}$Schwann cells $(\boldsymbol{E}, \boldsymbol{F})$, and Ly6G ${ }^{+}$neutrophils $(\boldsymbol{G}, \boldsymbol{H})$ in WT $(\boldsymbol{C}, \boldsymbol{E}, \boldsymbol{G})$ and $\left(\mathrm{Cr} 2^{-1-}(\boldsymbol{D}, \boldsymbol{F}, \boldsymbol{H})\right.$ nerves $7 \mathrm{~d}(\boldsymbol{C}-\boldsymbol{F})$ or $3 \mathrm{~d}(\boldsymbol{G}, \boldsymbol{H})$ after injury. All original images were cropped to the same size. Scale bar, $20 \mu \mathrm{m}$. $\boldsymbol{I}-\boldsymbol{K}$, Phagocytic indices of macrophages and dendritic cells $(\boldsymbol{I})$, neutrophils, fibroblasts, and endothelial cells $(\boldsymbol{J})$, and Schwann cells $(\boldsymbol{K})$ are not different between WT and $\mathrm{C}_{\mathrm{C} 2} 2^{-1-}$ nerves. Phagocytic indices of macrophages and Schwann cells are significantly increased for both genotypes between 3 and $7 \mathrm{~d}$ after injury. $I, n=1$ experiment, $n=593$ phagocytic $\mathrm{CD} 68^{+}$macrophages, $F_{(1,591)}=$ $17.53,{ }^{*} p=0.007,{ }^{* *} p<0.001$ (ANOVA). J, No statistical significance. $\boldsymbol{K}, n=1$ experiment, $n=351$ phagocytic GFAP ${ }^{+}$Schwann cells, $F_{(1,349)}=14.81,{ }^{*} p=0.024$ for WT, ${ }^{*} p=0.002$ for $\mathrm{Cr}^{-1-}$ (ANOVA). tissue sections and MBP as a myelin label. The percentage (Fig. $9 A$ ) and total number (Fig. $9 B$ ) of phagocytic cells were calculated at $3 \mathrm{~d}($ Fig. $9 \mathrm{C}-\mathrm{H})$ and $7 \mathrm{~d}($ Fig. 9I-N) after injury with MBP and either CD68, GFAP, or Ly6G to indicate phagocytosis by macrophages, Schwann cells, or neutrophils, respectively. Similar to the microsphere assay, a substantial increase in the percentage and total number of phagocytic macrophages was evident in WT mice compared with $\mathrm{Ccr} 2^{-1-}$ mice $7 \mathrm{~d}$ after injury. Furthermore, in $\mathrm{Ccr} 2^{-1-}$ nerves, there were significantly more phagocytic neutrophils compared with WT nerves at $3 \mathrm{~d}$ following injury. No changes in phagocytosis by Schwann cells were observed, which does not align with results from the microsphere assay. A possible explanation for the discrepancy is that different Schwann cell labels were used; GFAP, although a good label for immunocytochemistry, was replaced with p75 in the myelin phagocytosis assay because GFAP does not consistently label the entire cell in tissue sections. 
$C \times 3 c r 1^{-1-}$ mice and $C x 3 c r 1^{-/-}$mice treated with an anti-CCR2 antibody do not exhibit impaired myelin clearance in the sciatic nerve after injury

Because we do observe a significant increase in phagocytic macrophages in $\mathrm{Ccr} 2^{-1-}$ nerves between 3 and $7 \mathrm{~d}$ after injury, although smaller than in WT nerves, we considered the possibility that these CCR2 ${ }^{-}$macrophages were gaining entry from the blood via an alternative receptor. We assessed macrophage accumulation and myelin clearance in both $C \times 3 \mathrm{cr} 1^{-/-}$mice and mice with a double inhibition of CCR2 and CX3CR1. Double receptor inhibition was accomplished by injecting $C \times 3 \mathrm{cr} 1^{-1-}$ mice with the anti-CCR2 MC-21 antibody. WT mice treated with MC-67 were used as controls. Depletion of Ly6C ${ }^{+}$blood monocytes was confirmed using flow cytometry, with a small but significantly larger reduction of the total $\mathrm{Ly}_{6} \mathrm{C}^{+}$population in both MC-67- and MC-21-treated C $\times 3 \mathrm{cr} 1^{-1-}$ mice compared with WT mice (Fig. 10A,B).

In parallel with the attenuated blood monocyte population, $\mathrm{C} \times 3 \mathrm{cr} 1^{-1-}$ mice also showed a significantly reduced accumulation of $\mathrm{CD} 68^{+}$macrophages in the sciatic nerve $5 \mathrm{~d}$ after injury, which is comparable with that observed in WT mice treated with MC-21 to inhibit CCR2 (Fig. 10C-F). Our findings are in concert with those of others who used a model of chemotherapy-induced allodynia and observed a decrease in macrophage infiltration to the sciatic nerve in $\mathrm{C} \times 3 \mathrm{cr} 1^{-1-}$ mice compared with WT mice following vincristine treatment (Old et al., 2014). Nevertheless, this finding is unexpected because we do not observe an increase in Cx3cll mRNA at 6 or $48 \mathrm{~h}$ after injury (Fig. $6 C, D$ ). A viable possibility is that the loss of CX3CR1 decreases monocyte survival (Landsman et al., 2009) and therefore minimizes the total monocyte population. As all monocytes express CX3CR1 (Geissmann et al., 2003), it is conceivable that deletion of this receptor reduces macrophage accumulation not as a consequence of diminished monocyte chemotaxis, but due to the overall dwindling monocyte population.

Interestingly, double blockade of CCR2 and CX3CR1 did not have an additive effect on the inhibition of macrophage accumulation (Fig. 10C,F-G). Furthermore, similar to the $C \mathrm{cr} 2^{-1-}$ model, CX3CR1 deletion did not impede myelin clearance in the nerve $5 \mathrm{~d}$ after injury, despite a significant loss of macrophages (Fig. 10H-J). Myelin removal in the injured nerves was comparable between all genotypes, regardless of MC-21 treatment (Fig. $10 \mathrm{~K}, \mathrm{~L})$. These findings establish that deletion of CX3CR1 alone or inhibition of both CCR2 and CX3CR1 is not sufficient to impede WD.

\section{Neutrophil depletion inhibits myelin clearance}

To investigate whether neutrophils are necessary for myelin removal after sciatic nerve injury, neutrophils were depleted systemically using an anti-Ly6G antibody (Fig. 11A) (Daley et al., 2008). Efficiency of the depletion was determined by measuring neutrophils in the blood and nerve $3 \mathrm{~d}$ after injury, which coincides with the end stage of infiltration in the sciatic nerve (Perkins and Tracey, 2000). Neutrophils were depleted in the blood of WT and $\mathrm{Ccr} 2^{-1-}$ mice by $\sim 90 \%$ with anti-Ly6G antibody treatment compared with an isotype control (Fig. $11 B-E$ ). We confirmed that neutrophils were depleted by gating on the granularity property of neutrophils (Fig. $11 B, D$; CD $11 b^{+} \mathrm{SSC}^{\text {hi }}$ ). Side scatter intensity is directly proportional to cellular granularity; neutrophils, which have high cellular granularity (Segal, 2005), produce higher side scatter signals. Neutrophil depletion was also confirmed by gating on the $\mathrm{CD} 11 \mathrm{~b}^{+} \mathrm{Ly}_{6 \mathrm{G}}{ }^{+}$population (Fig. 11C,E). We observed using both methods of identification significant reductions in the total neutrophil population for WT and $\mathrm{Cr} 2^{-1-}$ mice. The reduction in blood neutrophils translated into depletion in the nerve at $3 \mathrm{~d}$ after injury (Fig. $11 F, G$ ). We observed no reduction in the neutrophil population in WT nerves between isotype control-treated and Ly6G-treated mice because the percentage of neutrophils in WT isotype-treated nerves was initially quite low.

Myelin removal was assayed $7 \mathrm{~d}$ after axotomy to determine how neutrophil depletion affects the near complete clearance process previously observed at this time point. While significant clearance was observed in both injured Ly6G- and isotypetreated mice of both genotypes (Fig. $11 H, J-M$ ) compared with sham-operated nerves (Fig. $11 \mathrm{H}$ ), removal was markedly stunted in neutrophil-depleted nerves, with a greater effect in $C \mathrm{cr} 2^{-1-}$ mice (Fig. 11I). Furthermore, the removal of MBP and myelin protein zero, two major proteins of peripheral nerve myelin (Patzig et al., 2011), was similarly assessed in isotype control- and Ly6G-treated mice (Fig. 12). Neutrophil-depleted Ccr2 ${ }^{-1-}$ nerves contained significantly more MBP $7 \mathrm{~d}$ after injury compared with its isotype control, whereas neutrophil-depleted WT nerves showed a trend toward significance (Fig. 12A-E). No differences were observed in myelin protein zero (Fig. 12A, F-I), although it is conceivable that small, yet notable, reductions in myelin protein zero would be difficult to discern due to this protein's high representation (45\%-70\%) (Patzig et al., 2011) of the total myelin composition in the peripheral nervous system.

\section{Discussion}

Infiltrating monocyte-derived macrophages have long been studied in the context of WD. Although peripheral nerve degeneration involves the actions of multiple cells, monocytes that infiltrate from the blood to the injury site have long been considered necessary for efficient debris clearance to occur (Beuche and Friede, 1984; Brück, 1997; Gaudet et al., 2011). Several studies using encapsulated dichloromethylene diphosphonate chlodronate liposomes or complement depletion methods to reduce the number of infiltrating monocytes slowed the rate of myelin clearance in the sciatic nerve after injury (Brück et al., 1996; Dailey et al., 1998; Liu et al., 2000).

A prior study that depleted $\mathrm{CD} 11 \mathrm{~b}^{+}$cells and observed a significant inhibition of myelin clearance in sciatic nerves $7 \mathrm{~d}$ after a crush injury attributed the deficit to the substantial loss of $\mathrm{CD} 8^{+}$macrophages (Barrette et al., 2008). However, CD11bexpressing neutrophils were similarly ablated in these experiments. We previously reported comparable myelin clearance in $\mathrm{Ccr} 2^{-1-}$ mice as in WT mice $7 \mathrm{~d}$ after axotomy, despite a significant decrease in macrophage accumulation in the $\mathrm{Cr} 2^{-1-}$ distal sciatic nerve (Niemi et al., 2013). We now show that the compensatory mechanism of WD that we identified in the $\mathrm{Ccr}^{-1-}$ mouse is mediated predominantly by neutrophils. Importantly, we find that neutrophils play a critical role in myelin clearance in both WT and $\mathrm{Ccr} 2^{-1-}$ mice, which is a function that has not been previously reported in the peripheral nervous system.

We also report that inhibiting infiltration of CCR $2{ }^{+}$monocytes also increased the number and percentage of phagocytosing Schwann cells between 3 and $7 \mathrm{~d}$ after injury, an effect that was not seen in WT mice. In support of our findings, in an Icam-1 $1^{-1-}$ mouse model that shows reduced monocyte extravasation, Schwann cells were shown to compensate for the loss of macrophages by increasing their uptake of myelin in the sciatic nerve after an injury (Vougioukas et al., 1998). While the overall removal of debris was inhibited in these mice, loss of the ICAM-1 intercel- 


\section{Blood}
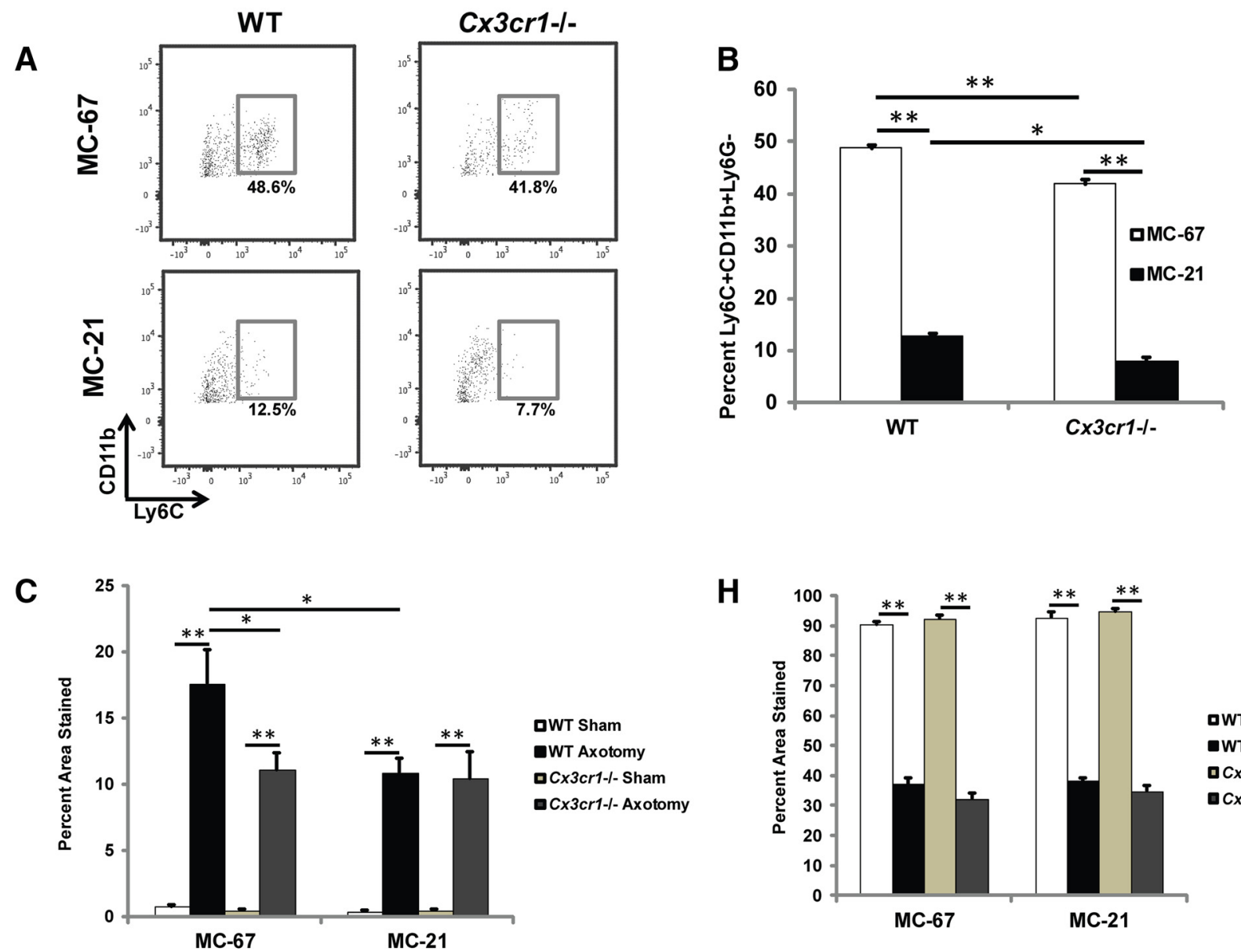

qWT Sham

WT Axotomy

口Cx3cr1-/-Sham

acx3cr1-I-Axotomy
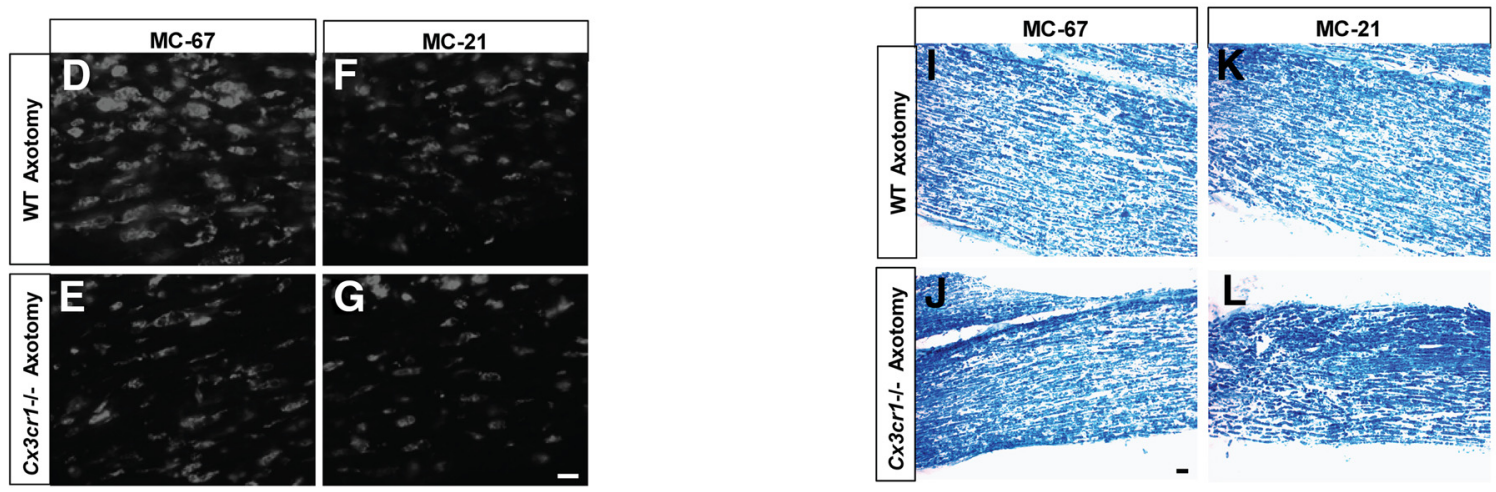

Figure 10. Double inhibition of $C$ CR2 and $C X 3 C R 1$ neither reduces macrophage accumulation in the nerve relative to the single knock-outs nor obstructs myelin clearance. $A, B$, Five days after

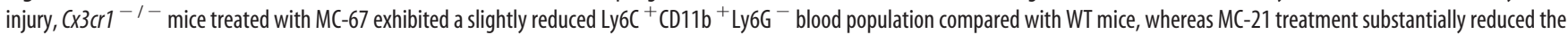
total Ly6C ${ }^{+}$monocyte population in both genotypes. $n=3$ mice per treatment. Between treatment: $F_{(1,10)}=1543.16,{ }^{* *} p<0.001$ (ANOVA); between genotypes: $F_{(1,10)}=42.07,{ }^{*} p=0.005$, ${ }^{* *} p<0.001$ (ANOVA). C, Accumulation of macrophages in sciatic nerves is represented as a percentage of the section area that was stained. $n=4$ or 5 mice per genotype per treatment. For MC-67, between injury: $F_{(1,16)}=77.57,{ }^{* *} p<0.001$ (ANOVA); between genotypes: $F_{(1,16)}=4.73,{ }^{*} p=0.010$ (ANOVA). For MC $-21, F_{(1,16)}=91.27,{ }^{* *} p<0.001$ (ANOVA). Between treatment: $F_{(1,34)}=$ $2.23,{ }^{*} p=0.001$ (ANOVA). D-G, Axotomized $\mathrm{C} \times 3 \mathrm{cr} 1^{-1-}$ nerves demonstrate reduced $\mathrm{CD} 68^{+}$macrophage accumulation $5 \mathrm{~d}$ after injury compared with axotomized WT nerves treated with $M C-67(\boldsymbol{D}, \boldsymbol{E})$. Double inhibition of CCR2 (MC-21) and CX3CR1 did not further attenuate the macrophage response in injured nerves $(\boldsymbol{F}, \boldsymbol{G})$. $\boldsymbol{H}-\boldsymbol{L}$, Quantification of myelin clearance using $L$ Luxol fast blue $(\boldsymbol{H})$ in MC-67-treated $(\boldsymbol{I}, \boldsymbol{J})$ or MC-21-treated $(\boldsymbol{K}, \boldsymbol{L})$ mice showed comparable removal of debris between all conditions $5 \mathrm{~d}$ after injury. $n=4$ mice per genotype per treatment. For MC-67, between injury: $F_{(1,16)}=1121.35,{ }^{* *} p<0.001$ (ANOVA). For MC-21, $F_{(1,14)}=1510.77,{ }^{* *} p<0.001$ (ANOVA). Scale bar, $20 \mu \mathrm{m}$.

lular adhesion molecule would also prevent neutrophil recruitment to the injured nerve (Yang et al., 2005).

Evaluating the role of Schwann cells in myelin removal reveals important considerations about mechanisms of ingestion. Recent evidence indicates that Schwann cells may not phagocytose myelin, but rather use autophagy proteins to facilitate myelin clearance during WD (Gomez-Sanchez et al., 2015). Schwann cell autophagy of myelin has also been implicated in a mouse model of peripheral neuropathy (Jang et al., 2016), underlining the importance of this process and the necessity for the distinction between phagocytosis and autophagy in inflammatory demyelinating conditions. In light of the compensatory role that 
A
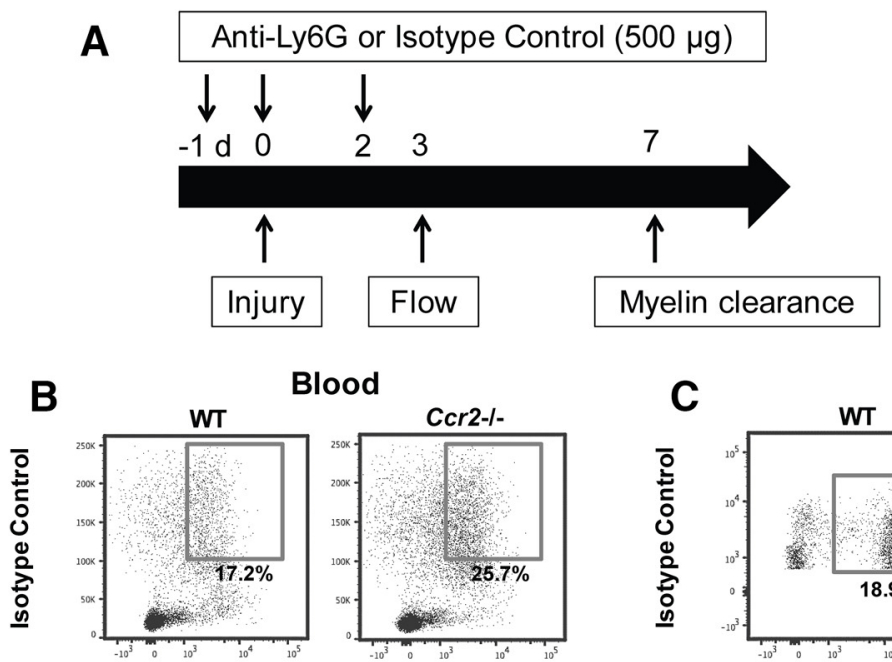

Blood
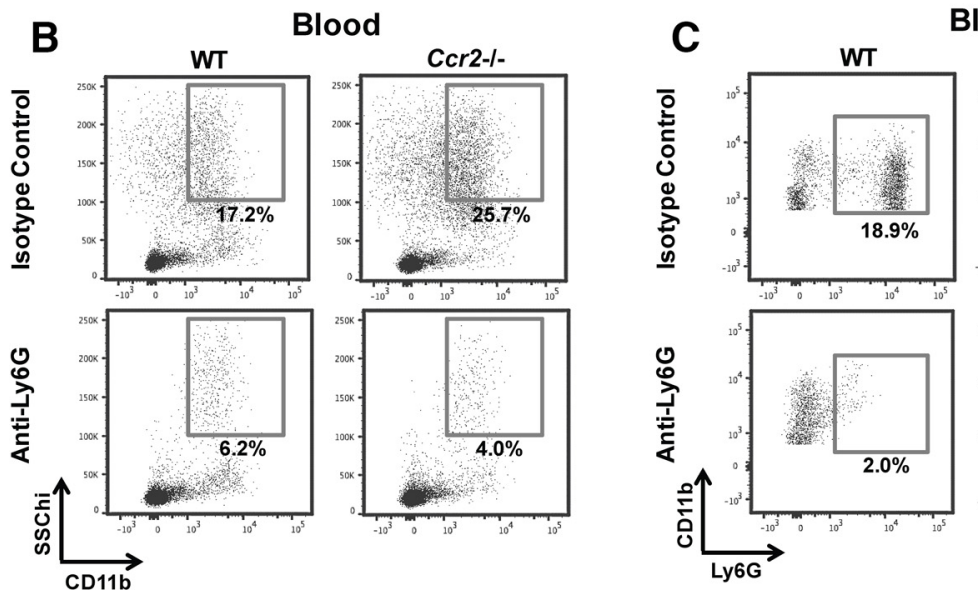

Blood

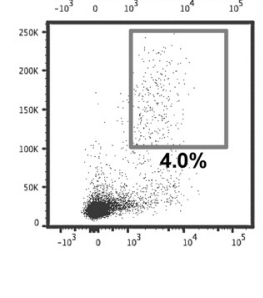

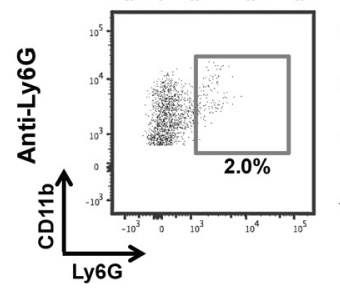

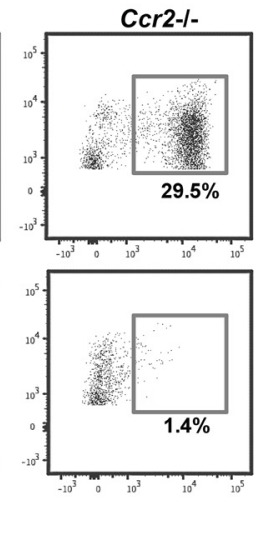

D

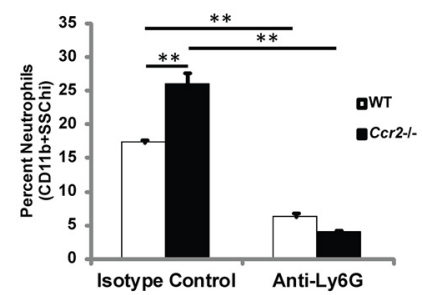

E

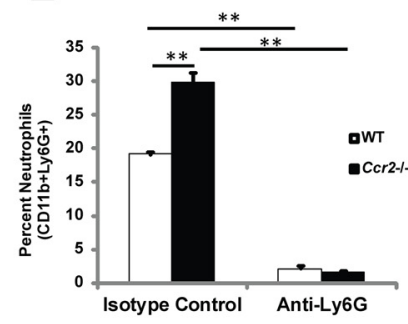

H

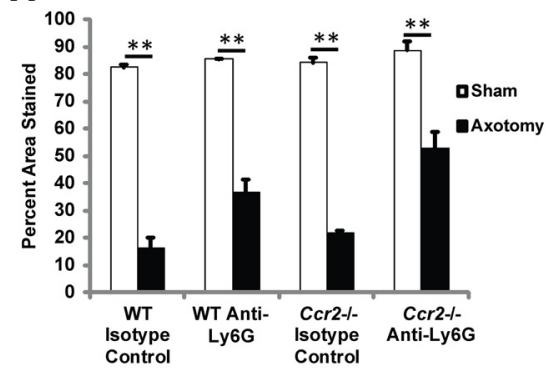

Nerve

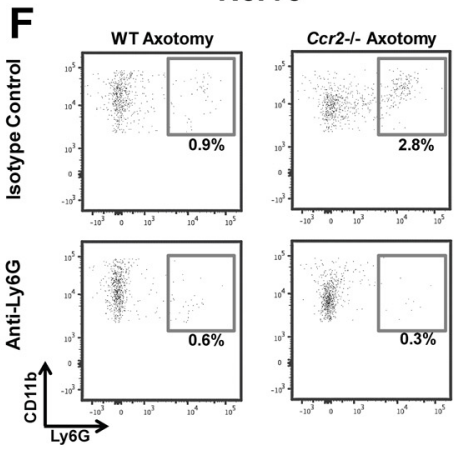

I

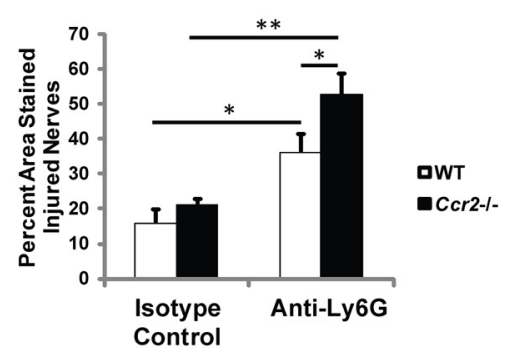

G

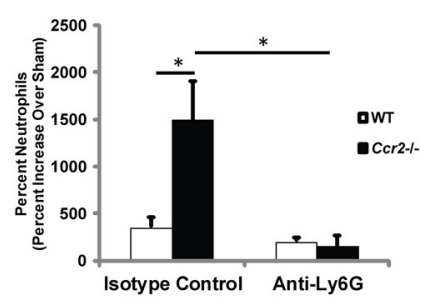

Figure 11. Neutrophil depletion significantly inhibits myelin clearance in $\left(\mathrm{Cr} 2^{-/}\right.$and WT nerves $7 \mathrm{~d}$ after injury. A-E, Mice were injected with an anti-Ly6G or isotype-matched control antibody according to the schematic $(\boldsymbol{A})$, and representative flow analyses of blood $3 \mathrm{~d}$ after axotomy in WT and $\left(\mathrm{Cr} 2^{-} /-\right.$mice confirmed neutrophil depletion after treatment with anti-Ly6G

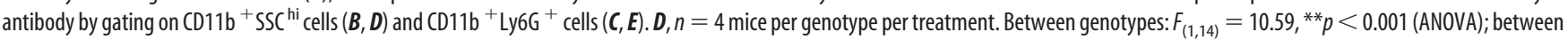
treatments: $F_{(1,14)}=281.31,{ }^{* *} p<0.001$ (ANOVA). $\boldsymbol{E}$, Between genotypes: $F_{(1,14)}=30.65,{ }^{* *} p<0.001$ (ANOVA); between treatments: $F_{(1,14)}=618.39,{ }^{* *} p<0.001($ ANOVA). $\boldsymbol{F}, \boldsymbol{G}$, A significant reduction in the accumulation of neutrophils in the nerve was also confirmed $3 \mathrm{~d}$ after injury. $n=4$ mice per genotype per treatment. Between genotypes: $F_{(1,10)}=6.27,{ }^{*} p=0.006($ ANOVA); between treatments: $F_{(1,10)}=11.7,{ }^{*} p=0.003$ (ANOVA). $\boldsymbol{H}, \mathbf{I}$, Quantification of myelin between groups 7 d after injury indicates that the loss of neutrophils significantly impedes clearance in both WT and $\left(\mathrm{Cr} 2^{-/-}\right.$nerves compared with isotype-matched controls. $n=5$ mice per genotype per treatment. For WT isotype control, $t_{(8)}=16.06 ;$ for WT anti-Ly6G, $t_{(8)}=9.57 ;$ for $\left(\mathrm{cr} 2^{-} /-\right.$isotype control, $t_{(8)}=27.44$; for $C\left(r 2^{-l-}\right.$ anti-Ly6G, $t_{(8)}=5.28,{ }^{* *} p<0.001$ (two-tailed $t$ test). $I$, This clearance defect has a greater effect on clearance in $C(r 2-l-$ nerves. Between genotypes: $F_{(1,18)}=5.97,{ }^{*} p=0.019$ (ANOVA); between treatments: $F_{(1,18)}=33.97,{ }^{*} p=0.005$ for WT, ${ }^{* *} p<0.001$ for $\left(c r 2^{-I-}\right.$ (ANOVA). J-M, Representative micrographs of isotype-treated axotomized $(\boldsymbol{J}, \boldsymbol{K})$ and Ly6G-treated axotomized $(\boldsymbol{L}, \boldsymbol{M}), \mathrm{WT}(\boldsymbol{J}, \boldsymbol{L})$, and $\left(\mathrm{Cr} 2^{-I-}(\boldsymbol{K}, \boldsymbol{M})\right.$ nerves. Scale bar, $20 \mu \mathrm{m}$. 
A
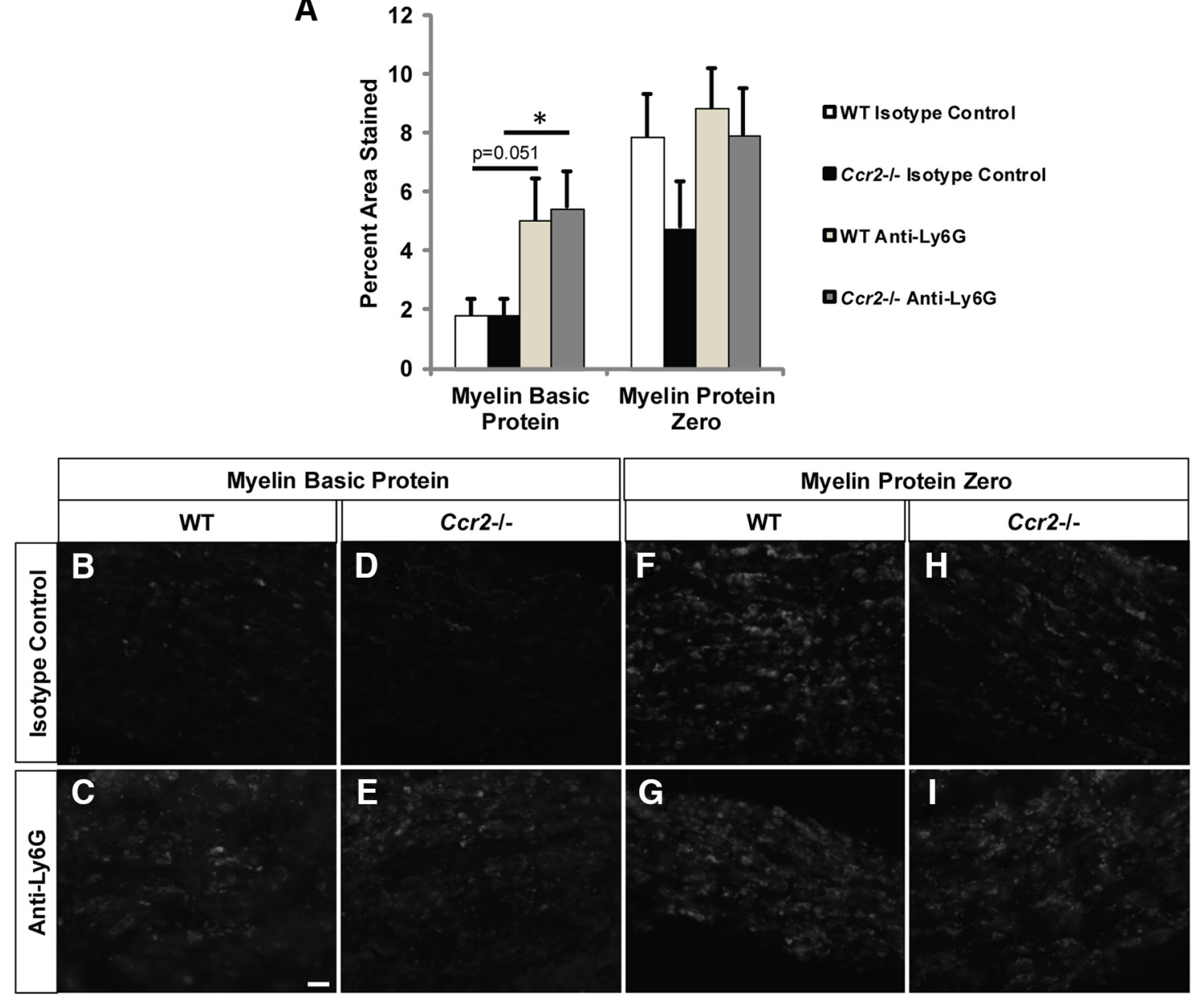

Figure 12. Clearance of MBP is inhibited in neutrophil-depleted nerves $7 \mathrm{~d}$ after sciatic nerve transection. $A$, MBP and myelin protein zero-labeled axotomized sciatic nerve sections from isotype control or Ly6G-treated WT and $C \mathrm{Cr} 2^{-1-}$ nerves are represented as percentage area stained. $n=5-7$ mice per genotype per treatment. $F_{(1,20)}=9.16 .{ }^{*} p=0.042$ for $C\left(\mathrm{cr} 2^{-} /-. p=0.051\right.$ for WT (not significant). $\boldsymbol{B}-\boldsymbol{E}$, Representative images show that removal of MBP after axotomy is inhibited in Ly6G-treated $\left(\boldsymbol{c r} 2^{-/-}\right.$nerves $(\boldsymbol{E})$ compared with isotype control-treated nerves $(\boldsymbol{D})$, with Ly6G-treated WT nerves $(\boldsymbol{C})$ showing a trend toward significance compared with isotype control-treated nerves $(\boldsymbol{B})$. $\boldsymbol{F}$-I, No effect is observed between treatments with myelin protein zero. Scale bar, $20 \mu \mathrm{m}$. No mice were excluded. However, quantification of percentage area stained described that for each mouse, three images per nerve were captured (quantification excluded the injury site and $\sim 1 \mathrm{~mm}$ distal to the injury site). For MBP ( 4 of 22 mice) and for myelin protein zero ( 1 of 22 mice), one of three of those images were excluded due to the values being outside the range of mean $\pm(2 \times S D)$

Schwann cells play in myelin removal in the $C c r 2^{-1-}$ mouse, future research into the cellular mechanisms of myelin clearance in this model should consider autophagy-related processes in addition to phagocytosis.

Aside from Schwann cells, we also observed a significant rise in the number and percentage of phagocytic CCR2 ${ }^{-}$macrophages in the $C \mathrm{cr} 2^{-1-}$ nerve between 3 and $7 \mathrm{~d}$ after injury. Through what receptor mechanism these CCR $2^{-}$macrophages infiltrate into the injured nerve is a question that needs to be answered. CCR5 is a likely alternative to CCR2 for this role in $\mathrm{Ccr} 2^{-1-}$ mice. CCR5's ligand, CCL5, has been reported as an important chemoattractant for macrophages in several models of peripheral neuroinflammation (Siebert et al., 2000; Ajuebor et al., 2001). Ccl5 ${ }^{-1-}$ mice show reduced macrophage accumulation after a partial sciatic nerve ligation injury (Liou et al., 2012), which perhaps highlights a possible molecular mechanism by which monocytes infiltrate into the injured $\mathrm{Ccr} 2^{-1-}$ nerve.

However, we cannot exclude the possibility that the increase in macrophage accumulation in $\mathrm{Ccr} 2^{-1-}$ nerves is due at least in part to resident cell proliferation (Mueller et al., 2003). Non$\mathrm{CCR} 2{ }^{+}$macrophages may also aid in myelin removal in the absence of CCR $2^{+}$macrophages. Under homeostatic conditions, resident macrophages proliferate and phagocytose debris and apoptotic cells independently of immune cell recruitment (Mosser and Edwards, 2008; Hashimoto et al., 2013). Resident macrophages begin to proliferate $2 \mathrm{~d}$ after sciatic nerve injury and, along with Schwann cells, readily phagocytose myelin debris before the appearance of hematogenous macrophages at 3-4 d after injury (Liu et al., 1995; Mueller et al., 2001; Hirata and Kawabuchi, 2002; Mueller et al., 2003; Ydens et al., 2012).

Although we report that a combination of cells compensates for the loss of CCR2 ${ }^{+}$macrophages in the $\mathrm{Cr} 2^{-1-}$ model, the data point to neutrophils as the most marked change relative to WT mice. Neutrophils depend mainly upon CXCR2 for chemoattractant recognition (Kolaczkowska and Kubes, 2013). CXCR2 binds to CXCL1, CXCL2, CXCL5, and CXCL8, all of which are produced predominantly by resident macrophages in response to various types of injury or inflammation (for a review, see Soehnlein and Lindbom, 2010). We report prolonged upregulation of both $\mathrm{Cxcl} 1$ and $\mathrm{Cxcl} 2 \mathrm{mRNA}$ in $\mathrm{Ccr} 2^{-1-}$ nerves compared with WT nerves, and observe an affiliated increase in both blood and nerve neutrophils in $\mathrm{Ccr} 2^{-1-}$ mice at $3 \mathrm{~d}$ after injury. This increased presence of phagocytic neutrophils is likely to account for the higher percentage of myelin clearance reported in $C c r 2^{-1-}$ 
nerves relative to WT nerves at that time point. Indeed, neutrophils also serve a pivotal role in myelin removal in WT mice, as we observe significant inhibition of WD when neutrophils are depleted.

Our study reveals a novel role for neutrophils in WD after nerve injury. However, the neutrophil's role as phagocyte is a function that has been well studied in other contexts. As the first line of defense against injury or infection, neutrophils phagocytose microbes and use lytic enzymes produced from their granule proteins to digest and remove foreign debris (Segal, 2005; Mantovani et al., 2011). Neutrophil-specific granule deficiency in both humans and rodents shows impaired monocyte extravasation from the bloodstream (Shiohara et al., 2004). Even more than that, neutrophil granules are important for macrophage differentiation, cytokine production, and, most relevantly to our data, phagocytosis (Soehnlein et al., 2009).

Neutrophils have been shown to alter macrophage phenotype (i.e., inflammatory or noninflammatory) through their contribution to the cytokine environment and through their direct physical contact upon macrophage engulfment of neutrophils. Neutrophil inflammatory and anti-inflammatory subsets similarly exist; and, like macrophages (Ydens et al., 2012), their functions are modulated by cellular changes and cytokine fluctuations in the tissue environment (de Oliveira et al., 2016). However, minimal characterization of neutrophil activation states in the context of nerve injury has been done, which presents an uncharted avenue for further exploration. Conversely, several studies have characterized the macrophage inflammatory state under various conditions and disease contexts. Macrophages have been shown to readily ingest apoptotic neutrophils and that during infection macrophages assume an anti-inflammatory phenotype after phagocytosing neutrophils, leading to increased production of arginase, IL-10, and TGF- $\beta$, and the subsequent resolution of inflammation (Savill et al., 1989; Cox et al., 1995; Huynh et al., 2002; Ribeiro-Gomes et al., 2004; Johann et al., 2007; Filardy et al., 2010). Cultured macrophages treated with supernatant from activated neutrophils showed increased macrophage surface expression of phagocytic receptors CD32 and CD64 and an attendant increased uptake and digestion of bacteria (Soehnlein et al., 2008). Furthermore, in an in vivo model of peritonitis infection, mice lacking neutrophils demonstrated reduced macrophage phagocytosis of bacteria (Gombart et al., 2005).

Conceivably, in our model, the loss of neutrophils after Ly6G treatment diminishes the phagocytic capability of macrophages both in WT and $\mathrm{Ccr}^{-1-}$ mice, which could in part explain the inhibition of myelin clearance in both genotypes. We find that macrophages remain a player in WD in the $C \mathrm{cr} 2^{-1-}$ mouse due to the increased number of phagocytic macrophages in the mutant nerve over time after injury. How neutrophils, which we have shown are critical for myelin removal, and macrophages, work in concert to facilitate WD is an intriguing unknown to be further explored.

Examining these questions will elucidate the functional nuances of non-neuronal cells during WD. We can later assess regeneration in the context of a full understanding of how nerve degeneration occurs-a necessity, as these two processes are inextricably linked. In addition, studies on WD may well have relevance to peripheral neuropathy present in a variety of diseases, such as Guillain-Barré syndrome and Charcot-Marie-Tooth (Martini et al., 2013). Finally, through studying degeneration in the peripheral nervous system, we can draw parallels to the cellular counterparts in the CNS that will provide insight into how to facilitate effective degeneration of damaged nerves to promote nerve regeneration.

\section{References}

Ajami B, Bennett JL, Krieger C, McNagny KM, Rossi FM (2011) Infiltrating monocytes trigger EAE progression, but do not contribute to the resident microglia pool. Nat Neurosci 14:1142-1149. CrossRef Medline

Ajuebor MN, Hogaboam CM, Kunkel SL, Proudfoot AE, Wallace JL (2001) The chemokine RANTES is a crucial mediator of the progression from acute to chronic colitis in the rat. J Immunol 166:552-558. CrossRef Medline

Amulic B, Cazalet C, Hayes GL, Metzler KD, Zychlinsky A (2012) Neutrophil function: from mechanisms to disease. Annu Rev Immunol 30:459489. CrossRef Medline

Auffray C, Fogg D, Garfa M, Elain G, Join-Lambert O, Kayal S, Sarnacki S, Cumano A, Lauvau G, Geissmann F (2007) Monitoring of blood vessels and tissues by a population of monocytes with patrolling behavior. Science 317:666-670. CrossRef Medline

Auffray C, Fogg DK, Narni-Mancinelli E, Senechal B, Trouillet C, Saederup N, Leemput J, Bigot K, Campisi L, Abitbol M, Molina T, Charo I, Hume DA, Cumano A, Lauvau G, Geissmann F (2009) CX3CR1 ${ }^{+}$CD115 ${ }^{+}$ $\mathrm{CD}_{135}{ }^{+}$common macrophage/DC precursors and the role of CX3CR1 in their response to inflammation. J Exp Med 206:595-606. CrossRef Medline

Barrette B, Hébert MA, Filali M, Lafortune K, Vallières N, Gowing G, Julien JP, Lacroix S (2008) Requirement of myeloid cells for axon regeneration. J Neurosci 28:9363-9376. CrossRef Medline

Beuche W, Friede RL (1984) The role of non-resident cells in Wallerian degeneration. J Neurocytol 13:767-796. CrossRef Medline

Bigbee JW, Yoshino JE, DeVries GH (1987) Morphological and proliferative responses of cultured Schwann cells following rapid phagocytosis of a myelin-enriched fraction. J Neurocytol 16:487-496. CrossRef Medline

Boivin A, Pineau I, Barrette B, Filali M, Vallières N, Rivest S, Lacroix S (2007) Toll-like receptor signaling is critical for Wallerian degeneration and functional recovery after peripheral nerve injury. J Neurosci 27:1256512576. CrossRef Medline

Borregaard N (2010) Neutrophils, from marrow to microbes. Immunity 33:657-670. CrossRef Medline

Brück W (1997) The role of macrophages in Wallerian degeneration. Brain Pathol 7:741-752. CrossRef Medline

Brück W, Huitinga I, Dijkstra CD (1996) Liposome-mediated monocyte depletion during Wallerian degeneration defines the role of hematogenous phagocytes in myelin removal. J Neurosci Res 46:477-484. CrossRef Medline

Brühl H, Cihak J, Plachý J, Kunz-Schughart L, Niedermeier M, Denzel A, Rodriguez Gomez M, Talke Y, Luckow B, Stangassinger M, Mack M (2007) Targeting of Gr-1 ${ }^{+}, \mathrm{CCR} 2^{+}$monocytes in collagen-induced arthritis. Arthritis Rheum 56:2975-2985. CrossRef Medline

Cox G, Crossley J, Xing Z (1995) Macrophage engulfment of apoptotic neutrophils contributes to the resolution of acute pulmonary inflammation in vivo. Am J Res Cell Mol Biol 12:232-237. CrossRef Medline

Dailey AT, Avellino AM, Benthem L, Silver J, Kliot M (1998) Complement depletion reduces macrophage infiltration and activation during Wallerian degeneration and axonal regeneration. J Neurosci 18:6713-6722. Medline

Daley JM, Thomay AA, Connolly MD, Reichner JS, Albina JE (2008) Use of Ly6G-specific monoclonal antibody to deplete neutrophils in mice. J Leukoc Biol 83:64-70. CrossRef Medline

de Oliveira S, Rosowski EE, Huttenlocher A (2016) Neutrophil migration in infection and wound repair: going forward in reverse. Nat Rev Immunol 16:378-391. CrossRef Medline

Dunay IR, Fuchs A, Sibley LD (2010) Inflammatory monocytes but not neutrophils are necessary to control infection with Toxoplasma gondii in mice. Infect Immun 78:1564-1570. CrossRef Medline

Filardy AA, Pires DR, Nunes MP, Takiya CM, Freire-de-Lima CG, RibeiroGomes FL, DosReis GA (2010) Proinflammatory clearance of apoptotic neutrophils induces an IL-12(low)IL-10(high) regulatory phenotype in macrophages. J Immunol 185:2044-2050. CrossRef Medline

Fujioka H, Tandler B, Hoppel CL (2012) Mitochondrial division in rat cardiomyocytes: an electron microscope study. Anat Rec (Hoboken) 295: 1455-1461. CrossRef Medline

Gao C, Xie R, Li W, Zhou J, Liu S, Cao F, Liu Y, Ma R, Si Y, Liu Y, Bi Y, Gilbert 
GE, Shi J (2013) Endothelial cell phagocytosis of senescent neutrophils decreases procoagulant activity. Thromb Haemost 109:1079-1090. CrossRef Medline

Gaudet AD, Popovich PG, Ramer MS (2011) Wallerian degeneration: gaining perspective on inflammatory events after peripheral nerve injury. J Neuroinflamm 8:110. CrossRef Medline

Geissmann F, Jung S, Littman DR (2003) Blood monocytes consist of two principal subsets with distinct migratory properties. Immunity 19:71-82. CrossRef Medline

George EB, Glass JD, Griffin JW (1995) Axotomy-induced axonal degeneration is mediated by calcium influx through ion-specific channels. J Neurosci 15:6445-6452. Medline

George R, Griffin JW (1994) Delayed macrophage responses and myelin clearance during Wallerian degeneration in the central nervous system: the dorsal radiculotomy model. Exp Neurol 129:225-236. CrossRef Medline

Gombart AF, Krug U, O’Kelly J, An E, Vegesna V, Koeffler HP (2005) Aberrant expression of neutrophil and macrophage-related genes in a murine model for human neutrophil-specific granule deficiency. J Leukoc Biol 78:1153-1165. CrossRef Medline

Gomez-Sanchez JA, Carty L, Iruarrizaga-Lejarreta M, Palomo-Irigoyen M, Varela-Rey M, Griffith M, Hantke J, Macias-Camara N, Azkargorta M, Aurrekoetxea I, De Juan VG, Jefferies HB, Aspichueta P, Elortza F, Aransay AM, Martínez-Chantar ML, Baas F, Mato JM, Mirsky R, Woodhoo A, et al. (2015) Schwann cell autophagy, myelinophagy, initiates myelin clearance from injured nerves. J Cell Biol 210:153-168. CrossRef Medline

Griffin JW, George R, Lobato C, Tyor WR, Yan LC, Glass JD (1992) Macrophage responses and myelin clearance during Wallerian degeneration: relevance to immune-mediated demyelination. J Neuroimmunol 40:153165. CrossRef Medline

Griffin JW, Wesselingh SL, Griffin DE, Glass JD, McArthur JC (1994) Peripheral nerve disorders in HIV infection: similarities and contrasts with CNS disorders. Res Publ Assoc Res Nerv Ment Dis 72:159-182. Medline

Hall SE, Savill JS, Henson PM, Haslett C (1994) Apoptotic neutrophils are phagocytosed by fibroblasts with participation of the fibroblast vitronectin receptor and involvement of a mannose/fucose-specific lectin. J Immunol 153:3218-3227. Medline

Hashimoto D, Chow A, Noizat C, Teo P, Beasley MB, Leboeuf M, Becker CD, See P, Price J, Lucas D, Greter M, Mortha A, Boyer SW, Forsberg EC, Tanaka M, van Rooijen N, García-Sastre A, Stanley ER, Ginhoux F, Frenette PS, et al. (2013) Tissue-resident macrophages self-maintain locally throughout adult life with minimal contribution from circulating monocytes. Immunity 38:792-804. CrossRef Medline

Hirata K, Kawabuchi M (2002) Myelin phagocytosis by macrophages and nonmacrophages during Wallerian degeneration. Microsc Res Tech 57: 541-547. CrossRef Medline

Huynh ML, Fadok VA, Henson PM (2002) Phosphatidylserine-dependent ingestion of apoptotic cells promotes TGF-betal secretion and the resolution of inflammation. J Clin Invest 109:41-50. CrossRef Medline

Imai T, Hieshima K, Haskell C, Baba M, Nagira M, Nishimura M, Kakizaki M, Takagi S, Nomiyama H, Schall TJ, Yoshie O (1997) Identification and molecular characterization of fractalkine receptor CX3CR1, which mediates both leukocyte migration and adhesion. Cell 91:521-530. CrossRef Medline

Jang SY, Shin YK, Park SY, Park JY, Lee HJ, Yoo YH, Kim JK, Park HT (2016) Autophagic myelin destruction by Schwann cells during Wallerian degeneration and segmental demyelination. Glia 64:730-742. CrossRef Medline

Jerath MR, Liu P, Struthers M, Demartino JA, Peng R, Peterson LB, Cumiskey AM, Yang L, Rojas M, Patel DD, Fong AM (2010) Dual targeting of CCR2 and CX3CR1 in an arterial injury model of vascular inflammation. Thromb J 8:14. CrossRef Medline

Johann AM, Barra V, Kuhn AM, Weigert A, von Knethen A, Brüne B (2007) Apoptotic cells induce arginase II in macrophages, thereby attenuating NO production. FASEB J 21:2704-2712. CrossRef Medline

Kluver H, Barrera E (1953) A method for the combined staining of cells and fibers in the nervous system. J Neuropathol Exp Neurol 12:400-403. CrossRef Medline

Kolaczkowska E, Kubes P (2013) Neutrophil recruitment and function in health and inflammation. Nat Rev Immunol 13:159-175. CrossRef Medline

Kurihara T, Warr G, Loy J, Bravo R (1997) Defects in macrophage recruit- ment and host defense in mice lacking the CCR2 chemokine receptor. J Exp Med 186:1757-1762. CrossRef Medline

Kuziel WA, Morgan SJ, Dawson TC, Griffin S, Smithies O, Ley K, Maeda N (1997) Severe reduction in leukocyte adhesion and monocyte extravasation in mice deficient in CC chemokine receptor 2. Proc Natl Acad Sci U S A 94:12053-12058. CrossRef Medline

Landsman L, Bar-On L, Zernecke A, Kim KW, Krauthgamer R, Shagdarsuren E, Lira SA, Weissman IL, Weber C, Jung S (2009) CX3CR1 is required for monocyte homeostasis and atherogenesis by promoting cell survival. Blood 113:963-972. CrossRef Medline

Leonard EJ, Skeel A, Yoshimura T (1991) Biological aspects of monocyte chemoattractant protein-1 (MCP-1). Adv Exp Med Biol 305:57-64. CrossRef Medline

Liou JT, Yuan HB, Mao CC, Lai YS, Day YJ (2012) Absence of C-C motif chemokine ligand 5 in mice leads to decreased local macrophage recruitment and behavioral hypersensitivity in a murine neuropathic pain model. Pain 153:1283-1291. CrossRef Medline

Liu HM, Yang LH, Yang YJ (1995) Schwann cell properties: 3. C-fos expression, bFGF production, phagocytosis and proliferation during Wallerian degeneration. J Neuropathol Exp Neurol 54:487-496. CrossRef Medline

Liu T, van Rooijen N, Tracey DJ (2000) Depletion of macrophages reduces axonal degeneration and hyperalgesia following nerve injury. Pain 86:2532. CrossRef Medline

Mack M, Cihak J, Simonis C, Luckow B, Proudfoot AE, Plachý J, Brühl H, Frink M, Anders HJ, Vielhauer V, Pfirstinger J, Stangassinger M, Schlöndorff D (2001) Expression and characterization of the chemokine receptors CCR2 and CCR5 in mice. J Immunol 166:4697-4704. CrossRef Medline

Mantovani A, Cassatella MA, Costantini C, Jaillon S (2011) Neutrophils in the activation and regulation of innate and adaptive immunity. Nat Rev Immunol 11:519-531. CrossRef Medline

Martini R, Klein D, Groh J (2013) Similarities between inherited demyelinating neuropathies and Wallerian degeneration: an old repair program may cause myelin and axon perturbation under nonlesion conditions. Am J Pathol 183:655-660. CrossRef Medline

Mosser DM, Edwards JP (2008) Exploring the full spectrum of macrophage activation. Nat Rev Immunol 8:958-969. CrossRef Medline

Mueller M, Wacker K, Ringelstein EB, Hickey WF, Imai Y, Kiefer R (2001) Rapid response of identified resident endoneurial macrophages to nerve injury. Am J Pathol 159:2187-2197. CrossRef Medline

Mueller M, Leonhard C, Wacker K, Ringelstein EB, Okabe M, Hickey WF, Kiefer R (2003) Macrophage response to peripheral nerve injury: the quantitative contribution of resident and hematogenous macrophages. Lab Invest 83:175-185. CrossRef Medline

Nadeau S, Filali M, Zhang J, Kerr BJ, Rivest S, Soulet D, Iwakura Y, de Rivero Vaccari JP, Keane RW, Lacroix S (2011) Functional recovery after peripheral nerve injury is dependent on the pro-inflammatory cytokines IL-1beta and TNF: implications for neuropathic pain. J Neurosci 31: 12533-12542. CrossRef Medline

Nahrendorf M, Swirski FK, Aikawa E, Stangenberg L, Wurdinger T, Figueiredo JL, Libby P, Weissleder R, Pittet MJ (2007) The healing myocardium sequentially mobilizes two monocyte subsets with divergent and complementary functions. J Exp Med 204:3037-3047. CrossRef Medline

Niemi JP, DeFrancesco-Lisowitz A, Roldán-Hernandez L, Lindborg JA, Mandell D, Zigmond RE (2013) A critical role for macrophages near axotomized neuronal cell bodies in stimulating nerve regeneration. J Neurosci 33:16236-16248. CrossRef Medline

Old EA, Nadkarni S, Grist J, Gentry C, Bevan S, Kim KW, Mogg AJ, Perretti M, Malcangio M (2014) Monocytes expressing CX3CR1 orchestrate the development of vincristine-induced pain. J Clin Invest 124:2023-2036. CrossRef Medline

Patzig J, Jahn O, Tenzer S, Wichert SP, de Monasterio-Schrader P, Rosfa S, Kuharev J, Yan K, Bormuth I, Bremer J, Aguzzi A, Orfaniotou F, Hesse D, Schwab MH, Möbius W, Nave KA, Werner HB (2011) Quantitative and integrative proteome analysis of peripheral nerve myelin identifies novel myelin proteins and candidate neuropathy loci. J Neurosci 31:16369_ 16386. CrossRef Medline

Perkins NM, Tracey DJ (2000) Hyperalgesia due to nerve injury: role of neutrophils. Neuroscience 101:745-757. CrossRef Medline

Perrin FE, Lacroix S, Avilés-Trigueros M, David S (2005) Involvement of monocyte chemoattractant protein-1, macrophage inflammatory protein- 
1alpha and interleukin-1beta in Wallerian degeneration. Brain 128:854-866. CrossRef Medline

Perry VH, Brown MC, Gordon S (1987) The macrophage response to central and peripheral nerve injury: a possible role for macrophages in regeneration. J Exp Med 165:1218-1223. CrossRef Medline

Ribeiro-Gomes FL, Otero AC, Gomes NA, Moniz-De-Souza MC, CysneFinkelstein L, Arnholdt AC, Calich VL, Coutinho SG, Lopes MF, DosReis GA (2004) Macrophage interactions with neutrophils regulate Leishmania major infection. J Immunol 172:4454-4462. CrossRef Medline

Saederup N, Cardona AE, Croft K, Mizutani M, Cotleur AC, Tsou CL, Ransohoff RM, Charo IF (2010) Selective chemokine receptor usage by central nervous system myeloid cells in CCR2-red fluorescent protein knock-in mice. PLoS One 5:e13693. CrossRef Medline

Savage JC, Jay T, Goduni E, Quigley C, Mariani MM, Malm T, Ransohoff RM, Lamb BT, Landreth GE (2015) Nuclear receptors license phagocytosis by trem $2{ }^{+}$myeloid cells in mouse models of Alzheimer's disease. J Neurosci 35:6532-6543. CrossRef Medline

Savill JS, Wyllie AH, Henson JE, Walport MJ, Henson PM, Haslett C (1989) Macrophage phagocytosis of aging neutrophils in inflammation: programmed cell death in the neutrophil leads to its recognition by macrophages. J Clin Invest 83:865-875. CrossRef Medline

Savina A, Amigorena S (2007) Phagocytosis and antigen presentation in dendritic cells. Immunol Rev 219:143-156. CrossRef Medline

Segal AW (2005) How neutrophils kill microbes. Annu Rev Immunol 23: 197-223. CrossRef Medline

Shiohara M, Gombart AF, Sekiguchi Y, Hidaka E, Ito S, Yamazaki T, Koeffler HP, Komiyama A (2004) Phenotypic and functional alterations of peripheral blood monocytes in neutrophil-specific granule deficiency. J Leukoc Biol 75:190-197. CrossRef Medline

Siebert H, Sachse A, Kuziel WA, Maeda N, Brück W (2000) The chemokine receptor CCR2 is involved in macrophage recruitment to the injured peripheral nervous system. J Neuroimmunol 110:177-185. CrossRef Medline
Soehnlein O, Lindbom L (2010) Phagocyte partnership during the onset and resolution of inflammation. Nat Rev Immunol 10:427-439. CrossRef Medline

Soehnlein O, Kai-Larsen Y, Frithiof R, Sorensen OE, Kenne E, ScharffetterKochanek K, Eriksson EE, Herwald H, Agerberth B, Lindbom L (2008) Neutrophil primary granule proteins HBP and HNP1-P3 boost bacterial phagocytosis by human and murine macrophages. J Clin Invest 118 : 3491-3502. CrossRef Medline

Soehnlein O, Weber C, Lindbom L (2009) Neutrophil granule proteins tune monocytic cell function. Trends Immunol 30:538-546. CrossRef Medline

Stoll G, Griffin JW, Li CY, Trapp BD (1989) Wallerian degeneration in the peripheral nervous system: participation of both Schwann cells and macrophages in myelin degradation. J Neurocytol 18:671-683. CrossRef Medline

Toews AD, Barrett C, Morell P (1998) Monocyte chemoattractant protein 1 is responsible for macrophage recruitment following injury to sciatic nerve. J Neurosci Res 53:260-267. CrossRef Medline

Vargas ME, Barres BA (2007) Why is Wallerian degeneration in the CNS so slow? Annu Rev Neurosci 30:153-179. CrossRef Medline

Vougioukas VI, Roeske S, Michel U, Brück W (1998) Wallerian degeneration in ICAM-1-deficient mice. Am J Pathol 152:241-249. Medline

Wang JT, Medress ZA, Barres BA (2012) Axon degeneration: molecular mechanisms of a self-destruction pathway. J Cell Biol 196:7-18. CrossRef Medline

Yang L, Froio RM, Sciuto TE, Dvorak AM, Alon R, Luscinskas FW (2005) ICAM-1 regulates neutrophil adhesion and transcellular migration of TNF- $\alpha$-activated vascular endothelium under flow. Blood 106:584-592. CrossRef Medline

Ydens E, Cauwels A, Asselbergh B, Goethals S, Peeraer L, Lornet G, AlmeidaSouza L, Van Ginderachter JA, Timmerman V, Janssens S (2012) Acute injury in the peripheral nervous system triggers an alternative macrophage response. J Neuroinflamm 9:176. CrossRef Medline 